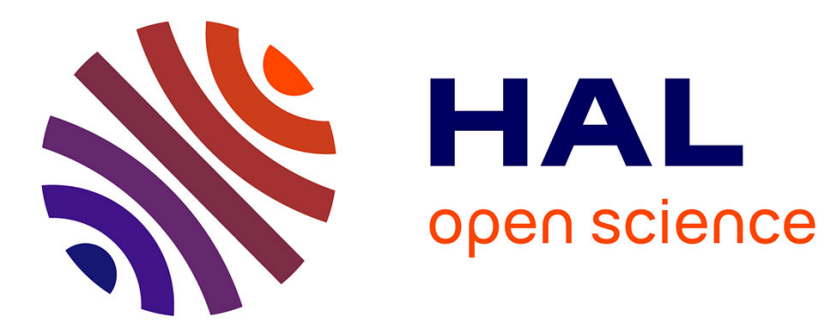

\title{
How do food sources drive meiofauna community structure in soft-bottom coastal food webs?
}

L.H. van Der Heijden, J. Rzeznik-Orignac, R. Asmus, D. Fichet, M. Bréret, P. Kadel, L. Beaugeard, H. Asmus, B. Lebreton

\section{- To cite this version:}

L.H. van Der Heijden, J. Rzeznik-Orignac, R. Asmus, D. Fichet, M. Bréret, et al.. How do food sources drive meiofauna community structure in soft-bottom coastal food webs?. Marine Biology, 2018, 165 (10), pp.166. 10.1007/s00227-018-3419-7 . hal-01994251

\section{HAL Id: hal-01994251 \\ https://hal.science/hal-01994251}

Submitted on 18 Feb 2021

HAL is a multi-disciplinary open access archive for the deposit and dissemination of scientific research documents, whether they are published or not. The documents may come from teaching and research institutions in France or abroad, or from public or private research centers.
L'archive ouverte pluridisciplinaire HAL, est destinée au dépôt et à la diffusion de documents scientifiques de niveau recherche, publiés ou non, émanant des établissements d'enseignement et de recherche français ou étrangers, des laboratoires publics ou privés. 
1 How do food sources drive meiofauna community structure in soft-bottom coastal food webs?

2 L.H. van der Heijden ${ }^{1,2}$, J. Rzeznik-Orignac ${ }^{3}$, R. Asmus ${ }^{2}$, D. Fichet ${ }^{1}$, M. Bréret ${ }^{1}$, P. Kadel ${ }^{2}$, L. Beaugeard ${ }^{1}$, 3 H. Asmus ${ }^{2}$, B. Lebreton ${ }^{1}$

$4{ }^{1}$ UMR 7266 Littoral, Environnement et Sociétés (CNRS - University of La Rochelle), Institut du littoral et 5 de l'environnement, 2 rue Olympe de Gouges, 17000 La Rochelle, France

$6 \quad{ }^{2}$ Alfred-Wegener-Institut Helmholtz-Zentrum für Polar-und Meeresforschung, Wattenmeerstation Sylt,

$7 \quad$ Hafenstrasse 43, 25992 List/Sylt, Germany

$8{ }^{3}$ Sorbonne Universités, UPMC Univ Paris 06, CNRS, Laboratoire d'Ecogéochimie des Environnements

9 Benthiques (LECOB UMR 8222), Observatoire Océanologique, 66650 Banyuls/mer, France

11 Corresponding author: L.H. van der Heijden

12 Email address: luuk.van_der_heijden@univ-lr.fr

13 Phone number: +33 (0) 546507631 


\section{Abstract}

Meiofauna have a strong role in the functioning of coastal ecosystems but how their food sources affect their community structure remains unclear, likely due to the influence of abiotic parameters and the small size of these organisms. The meiofauna and their potential food sources were sampled in several intertidal habitats (i.e. mudflat, seagrass bed, sandflat) of the Marennes-Oléron Bay, France, and the SyltRømø Bight, Germany, to assess the relationships between habitat characteristics and meiofauna community structure. Biomass and quality (carbon/chlorophyll $a$ ratios) of food sources were estimated. Meiofauna community structure based on density and biomass was determined, as well as nematode diversity and feeding types. Meiofauna density and biomass varied highly within habitats and within ecosystems, ranging from $1.7 * 10^{5}$ ind. $\mathrm{m}^{-2}$ to $3.4^{*} 10^{6}$ ind. $\mathrm{m}^{-2}$ and from $0.057 \mathrm{gC} \mathrm{m}^{-2}$ to $1.541 \mathrm{gC} \mathrm{m}^{-2}$, respectively. Benthic microalgae and sediment organic matter are important drivers in these food webs as the density of two important trophic groups of nematodes, non-selective deposit feeders and epigrowth feeders, varied in accordance with these food sources. No clear relationship was observed between bacterial biomass and selective deposit feeders (i.e. bacterivores) probably due to the high production rate of bacteria. Complementary information about production rates of food source as well as data from trophic markers would provide complimentary information to better understand flows of organic matter in intertidal habitats, particularly for opportunistic species such as non-selective deposit feeders.

\section{Introduction}

Soft-bottom intertidal habitats are highly productive (Underwood and Kromkamp 1999; Hemminga and Duarte 2000), fueling complex food webs and providing food resources for a large diversity of top consumers like fish and birds (Day et al. 1989; Duarte and Cebrián 1996) via trophic pathways going through meiofauna (Chardy and Dauvin 1992) and macrofauna (Haubois et al. 2005). Meiofauna, here defined as metazoans associated with sediments with a size range from 40 to $500 \mu \mathrm{m}$, are considered as an important trophic component in the functioning of coastal ecosystems. They have an intermediate trophic position (Leguerrier et al. 2003; Giere 2009) and high secondary production (from 4 to $29 \mathrm{gC} \mathrm{m}^{-2}$ year $\left.^{-1}\right)$ (Escaravage et al. 1989; Chardy and Dauvin 1992; Danovaro et al. 2002) that often exceeds that of the macrofauna (Giere 2009). Meiofauna are connected to the microorganisms in the food web via the consumption of microalgae and bacteria (Rzeznik-Orignac et al. 2003; Vafeiadou et al. 2014) and to the food webs of macroconsumers especially via their consumption by small benthic fish and predatory invertebrates (Coull 1999). Nematodes are the most dominant group in meiofauna; their food resources can be very specific, or in the contrary, relatively diverse, and their buccal cavity is very distinct based on these feeding types. This morphological trait has been used for decades to define feeding types (Wieser 1953; Warwick 1971; Heip et al. 1985) and some more recent methods (i.e. feeding behavior 
experiments; (Moens and Vincx 1997), trophic markers (Moens et al. 2005)) permitted to revise or precise the feeding types of some genera (e.g. assort of Metachromadora from the omnivores/predators to the epigrowth feeders).

Both, biotic and abiotic parameters, have been shown to affect meiofauna community structure. Among biotic parameters, food availability in general (Castel et al. 1989; Danovaro 1996), availability of specific food sources such as bacteria and microphytobenthos (Danovaro and Gambi 2002; Fonseca et al. 2011), the quality of the food (Danovaro et al. 2002) and the deposition of organic material of pelagic origin (Franco et al. 2008) have been identified as structuring parameters. Abiotic parameters such as sediment grain-size (Steyaert et al. 2003; Dupuy et al. 2015), habitat structure (Fonseca et al. 2011), oxygen gradients (Josefson and Widbom 1988), intertidal water level (Steyaert et al. 2001) as well as anthropogenic impacts (Semprucci et al. 2010) are influencing meiofauna community structure. Studies on meiobenthic communities in intertidal systems have been carried out mainly on single habitats, focusing on effects of abiotic and biotic parameters at the habitat scale (Reise 1985; Rzeznik-Orignac et al. 2003; Lebreton et al. 2012). Factors affecting the community structure of meiofauna at a larger scale (Moens et al. 2013) in intertidal habitats are still poorly known, as few studies have compared several habitats and/or different ecosystems.

The present study investigates whether meiobenthic communities, especially free-living nematodes and benthic copepods, differ among habitats with different characteristics (i.e. mudflats, seagrass beds and sandflats; influence of terrestrial organic matter inputs or not) to define which factors are structuring these communities. Particular attention is paid to the role of food sources, as they have been highlighted as important drivers of ecosystem functioning in intertidal habitats (Asmus and Asmus 1985; Underwood and Kromkamp 1999; McLusky and Elliott 2004). Aim of this study is therefore to define if changes in biomass and quality of food sources can affect meiofauna community structure. If yes, the objective is to determine — among all available food sources (i.e. benthic microalgae, sediment organic matter (SOM), suspended particulate organic matter (SPOM) and bacteria)—what food sources play a role and how changes in these food sources influence meiofauna community structure. In this aim, a temporal sampling was donine in spring and autumn in several habitats to define the temporal and spatial variations of the food sources and those of meiofauna community structure.

\section{Materials and methods}

\section{Study sites}

\section{Marennes-Oléron Bay}


The Marennes-Oléron Bay is a semi-enclosed system, located in the middle of the western Atlantic coast of France, between the Oléron Island and the mainland (Fig. 1). The bay has a surface of $180 \mathrm{~km}^{2}$ (Gouleau et al. 2000) and is influenced by both oceanic and continental inputs, mainly from the Charente River (river input ranges from 15 to $500 \mathrm{~m}^{3} \mathrm{~s}^{-1}$ ) (Ravail et al. 1988). Tides are semi-diurnal, with a period of emersion of ca. $6 \mathrm{~h}$ per tidal cycle and a tidal range from 0.9 to $6.5 \mathrm{~m}$ (Kervella 2009). The system is dominated by intertidal bare mudflats $\left(91 \mathrm{~km}^{2}\right.$, i.e. $\left.58 \%\right)$ which have a flat bottom slope $(1: 1000)$ and represent a large tidal area (up to $4.5 \mathrm{~km}$ wide) (Gouleau et al. 2000).

The Brouage mudflat, located on the eastern part of the bay, is the most extensive mudflat $\left(40 \mathrm{~km}^{2}\right)$ (Fig. 1). The sediment consists mainly of silt and clay particles (95\%) with a size smaller than $63 \mu \mathrm{m}$ (Pascal et al. 2009). Seagrass beds, consisting of the species Zostera noltii (Lebreton et al. 2009), are located on the western side of the bay, along the coast of the Oléron Island, which is more influenced by offshore waters than the eastern side (Dechambenoy et al. 1977). The seagrass meadow is stretched out over $15 \mathrm{~km}$ along the upper part of the flat, with an average width of $1.5 \mathrm{~km}$ (Guillaumont 1991).

\section{Sylt-Rømø Bight}

The Sylt-Rømø Bight is a semi-enclosed basin, located in the north of Germany between the mainland of Germany and Denmark, the islands of Sylt (Germany) and of Rømø (Denmark) (Fig. 1). The bight consists of a mosaic of habitats, mainly intertidal and subtidal sandflats, seagrass beds, and mudflats (Asmus and Asmus 1985). The bight has a coverage of $404 \mathrm{~km}^{2}$ of which $135 \mathrm{~km}^{2}$ are intertidal (Asmus and Asmus 1985) and the tidal gauge is $1.8 \mathrm{~m}$ on average (Asmus and Asmus 1985).

The Arenicola sandflat is the most represented intertidal habitat in the bay with $91 \mathrm{~km}^{2}(67 \%)$ (Asmus and Asmus 2005). However, Zostera noltii seagrass beds expanded over the last years, from 15 $\mathrm{km}^{2}$ in 1995 to $83 \mathrm{~km}^{2}$ (i.e. $21 \%$ of the bay surface) in 2010 (Reise and Kohlus 2008). The intertidal bare mudflats are poorly represented in the bight, with an area of $4 \mathrm{~km}^{2}$ (Fig. 1).

\section{Field sampling and laboratory processes}

Three intertidal habitats were studied in the two bays: a bare mudflat (mudflat MO) and a seagrass bed (seagrass MO) in the Marennes-Oléron Bay, and a bare mudflat (mudflat SR), a seagrass bed (seagrass SR) and a sandflat (sandflat SR) in the Sylt-Rømø Bight (Fig. 1). Based on knowledge already gained about these habitats in each of these five locations (Leguerrier et al. 2003; Baird et al. 2007; Pacella et al. 2013; Saint-Béat et al. 2013) one sampling station that was the most representative for the studied habitat was selected. 


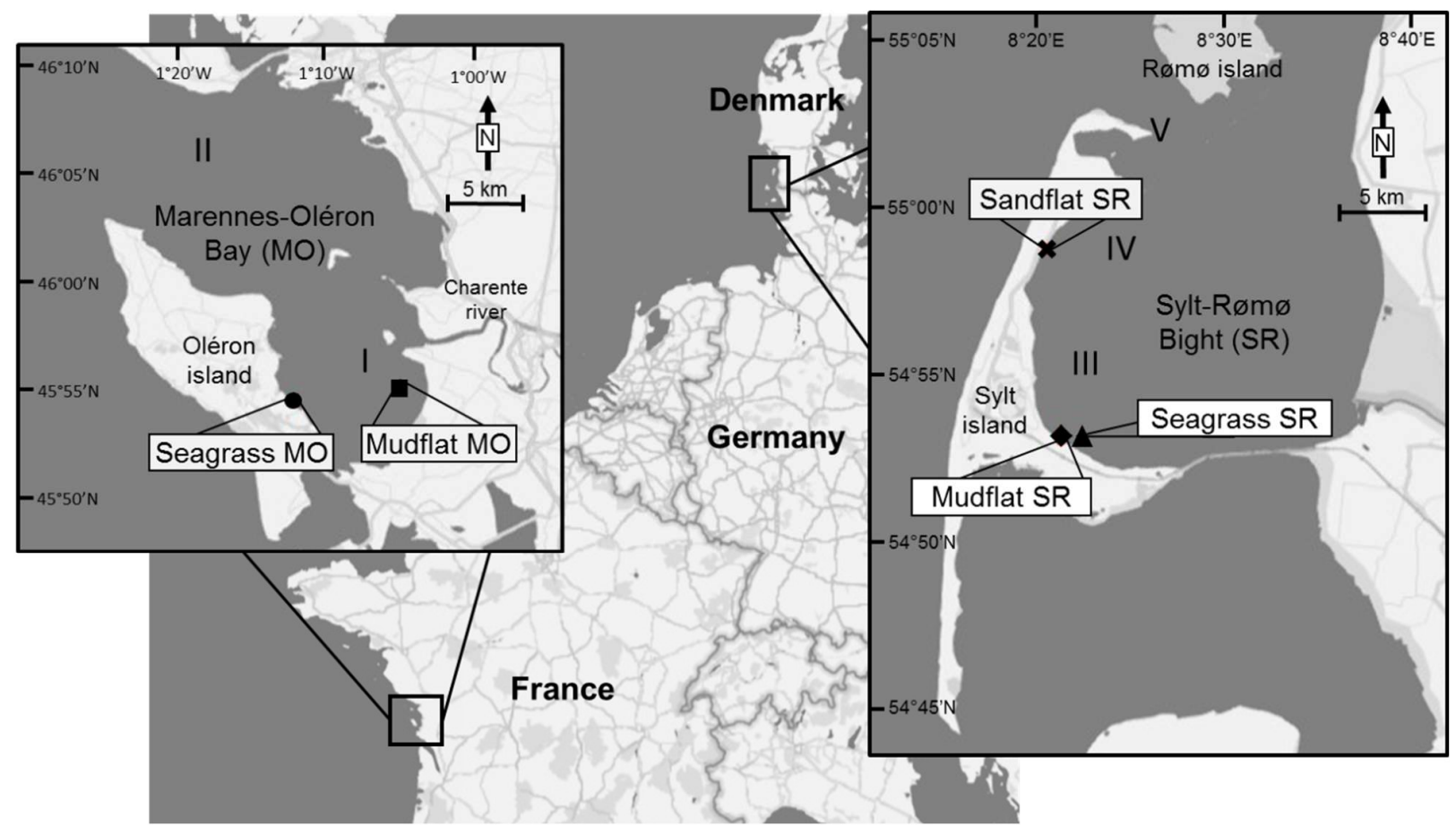

Figure 1. Sampling stations of the mudflats, seagrass beds and sandflat in the Marennes-Oléron Bay (MO) and the Sylt-Rømø Bight (SR) along the European coast. Pelagic sampling stations, where samples for suspended particulate organic matter were taken, are indicated by roman numbers in both Marennes-Oléron Bay (I-II) and Sylt-Rømø Bight (III-V).

\section{Sediment grain size}

Sediment samples $(n=3)$ were collected randomly with cores $(\varnothing=4 \mathrm{~cm})$ and were split into $0-1 \mathrm{~cm}$ and $1-5 \mathrm{~cm}$ depth fractions. Sediment grain size was determined by laser granulometry analyses for the sediment from the seagrass bed and mudflats (Mastersize 2000, Malvern Instruments Limited, United Kingdom). The freeze-dried sediment of these habitats was rehydrated before analyses in order to avoid the use of ultrasound to disaggregate the sediment. Sediment grain size of freeze-dried samples from the sandflat of the Sylt-Rømø Bight was determined by dry sieving. Samples were classified based on their median sediment grain size after Wentworth (1922).

\section{Benthic primary producers, composite sources and bacteria}

For all stations, sampling was carried out in two seasons, in spring (from May 17 to June 17, 2016) and in autumn (from November 14 to December 15, 2016), to compare a season with a high primary production with a season with a high load of detrital matter. Sampling was carried out during low tide, starting about one hour before lowest water level. 
Samples for sediment organic matter (SOM), detritus, and seagrass leaves and roots (3 replicates) were taken using cores $(\varnothing=19 \mathrm{~cm}$ ) which were separated in two layers (a surface layer from $0-1 \mathrm{~cm}$, a sub-surface layer from $1-5 \mathrm{~cm})$. The collected material was gently sieved on a $500 \mu \mathrm{m}$ mesh screen $(1$ $\mathrm{mm}$ for sandflat SR samples) after which the upper fraction was sorted in seagrass leaves, roots and detritus (brown to black colored leaves and roots). All samples were freeze-dried, then weighed $( \pm 0.001$ g). Carbon to dry weight ratios were determined on each sample: A small amount was ground to a fine and homogeneous powder using a ball mill (MM 400, Retsch, Germany) and carbon content was determined using an elemental analyzer (Flash EA 1112, Thermo Scientific, Italy). Subsamples were collected in the lower fraction (SOM), freeze-dried, and ground using a mortar and pestle. Chlorophyll $a$ and organic carbon concentrations were determined in sub-samples by fluorimetry (TD-700, Turner Designs, USA) using the method of Lorenzen (1966) and elemental analyses (Flash EA 1112, Thermo Scientific, Italy), respectively. Chlorophyll $a$ values were converted into carbon biomass using the conversion ratio (47.63) provided by de Jonge (1980) and used as a proxy of fresh material of microalgae origin (i.e. microphytobenthos and trapped phytoplankton) in sediment, thereafter called "benthic microalgae". Carbonates were removed prior to elemental analyses by adding $\mathrm{HCl}$ at 2 mol..$^{-1}$ drop-bydrop on SOM samples until cessation of bubbling. Subsequently samples were dried at $60^{\circ} \mathrm{C}$ to constant weight, freeze-dried and ground again.

Bacterial biomass ( 3 replicates) was determined using cores $(\varnothing=4 \mathrm{~cm})$ which were separated in two layers $(0-1 \mathrm{~cm}$ and $1-5 \mathrm{~cm})$. These sediment layers were homogenized with a spatula and $2 \mathrm{~mL}$ of this material were mixed with $2 \mathrm{~mL}$ formalin (4\%). Samples were deep frozen in liquid nitrogen and stored at $-80^{\circ} \mathrm{C}$. The number of bacteria was determined following the protocol of Lavergne et al. (2014). Samples were diluted (1/2000) using sodium pyrophosphate (P-8010, Sigma Aldrich, France) and Tween 80 (P1754, Sigma Aldrich, France), homogenized and then incubated at $4{ }^{\circ} \mathrm{C}$ during 30 minutes. Samples were then sonicated at $60 \mathrm{~W}$ during 30 seconds, after which $1 \mathrm{~mL}$ of the pre-diluted sample was stained with 20 $\mu \mathrm{L}$ of SYBR Green I (Invitrogen-11540746; 1/5000 final concentration) and incubated in the dark at room temperature for 15 minutes. Afterwards, $2 \mu \mathrm{L}$ of calibration beads $(1 \mu \mathrm{M})$ were added and the samples were analyzed using a flow cytometer (BD FACSCANTO II, BD Biosciences, USA). Bacterial densities were converted into carbon using the conversion factor $\left(20 \mathrm{fgC} \mathrm{cell}^{-1}\right)$ established by Lee and Fuhrman (1987).

\section{Suspended particulate organic matter}

Sampling of the suspended particulate organic matter (SPOM) was conducted by collecting samples of surface water during high tide, in the same timeframe as the benthic samples. Water was sampled at two stations (I and II) in the Marennes-Oléron Bay and three stations (III, IV and V) in the Sylt-Rømø 
Bight (Fig. 1). Station I, in the north of the Brouage mudflat, represented the water mass covering the mudflat MO station. Station II, near the inlet of the Marennes-Oléron bay, represented the water mass influencing the seagrass MO station. Station II is regularly sampled in the framework of the SOMLIT surveys (data provided by “Service d'Observation en Milieu Littoral, INSU-CNRS, La Rochelle station”). Water samples collected at stations III and IV represented water masses covering the sandflat SR (III), and the mudflat SR and seagrass SR stations (IV), respectively. Station V, near the entrance of the SyltRømø Bight, represented the SPOM originating from the North Sea.

SPOM was sampled by collecting 10 to $100 \mathrm{~mL}$ of surface seawater which was pre-filtered on a 250$\mu \mathrm{m}$ mesh screen to eliminate large particles/organisms. Water samples were then filtered on precombusted ( 4 hours, $450^{\circ} \mathrm{C}$ ) Whatman $\mathrm{GF} / \mathrm{F}$ glass fiber filters $(0.7 \mu \mathrm{m}$ nominal porosity) under moderate vacuum and these filters were freeze-dried. Chlorophyll $a$ content, used as a proxy of phytoplankton biomass, of the freeze-dried GF/F filters was measured by fluorimetry using the method of Lorenzen (1966). Phytoplankton biomass was determined by using the conversion factor (56.4) established by Lü et al. (2009).

\section{Meiofauna}

Meiofauna was sampled for taxonomic composition, density (ind. $\mathrm{m}^{-2}$ ) and biomass $\left(\mathrm{gC}^{-2}\right)$ estimations at the same time as benthic primary producers and composite sources. Three replicates were collected randomly in a ten square meters area using cores $(\varnothing=4 \mathrm{~cm})$. Cores were separated in two layers (0-1 cm and $1-5 \mathrm{~cm})$ to study the changes of meiofauna communities related to sediment depth. Samples were sieved with a 500- $\mu \mathrm{m}$ mesh to eliminate macrofauna and large detritus. Meiofauna was extracted from the sediment using Ludox HS-40 (Sigma Aldrich, France) (de Jonge and Bouwman 1977) and retrieved with a 40- $\mu \mathrm{m}$ mesh sieve (Higgins and Thiel 1988). From each replicate, 100 nematodes were haphazardly taken with fine tweezers (\#55, Dumont, Switzerland), mounted on slides in anhydrous glycerol to prevent dehydration (Seinhorst 1959) and examined microscopically. The taxonomic composition of the nematode community was determined at least to the genera level based on these 100 individuals according to the identification keys of Platt and Warwick (1983, 1988), and Warwick and Clarke (1998). Density was calculated for each genera as number of individuals per $\mathrm{m}^{2}$ (ind. $\mathrm{m}^{-2}$ ) and relative abundance as the percent composition of each genera relative to the total number of organisms. Species diversity indices were calculated on 100 individuals for each replicate at the five habitats for the two seasons. Community structure of the other meiofauna groups was not determined due to low densities. Nematodes were allocated into four trophic groups according to Wieser (1953) as follows: selective deposit-feeders (1A), non-selective deposit-feeders (1B), epigrowth feeders (2A), and omnivores/predators (2B). Various nematode genera, including at least one of each from the 4 different 
feeding groups, were selected for determination of individual dry weight and carbon content. Between 10 and 200 nematodes from the same genera were picked for dry weight determination, freeze-dried and weighed $( \pm 1 \mu \mathrm{g})$ using a microbalance (ME 5, Sartorius, Germany). Organic carbon composition was determined using an elemental analyzer (Flash EA 1112, Thermo Scientific, Italy). Mean biomass of species-specific nematodes and benthic copepods were used to convert the density of nematodes into grams of carbon per $\mathrm{m}^{2}$ and dry weight per $\mathrm{m}^{2}$ (Supplementary material, Appendix 1).

\section{Data treatment and statistical methods}

All analyses were conducted using the R software (R Core Team, 2016) and all hypotheses were tested at $\mathrm{p}<0.05$ level. Normality of the data was tested using Shapiro-Wilks tests. Homogeneity of variance was checked using Bartlett and Levene tests. Average hierarchical clusters (data dissimilarity, Bray-Curtis distance) were realized to discriminate groups within the food sources and within the meiofauna trophic structure using the vegan package (Oksanen et al. 2017) and pvclust package (Suzuki and Shimodaira 2015). ANOVA followed by Tukey post-hoc test were used to compare sediment characteristics, meiofauna densities, biomass and diversity indices: Hill's diversity $\mathrm{N}_{1}$ (Hill 1973) and species evenness $J$ ' (Formula in supplementary material, Appendix 2). Comparisons between sediment layers were conducted on meiofauna densities (ind. $\left.\mathrm{m}^{-3}\right)$ and biomasses $\left(\mathrm{gC} \mathrm{m}^{-3}\right)$ expressed in volume of sediment. Comparisons between seasons and habitats were done on meiofauna densities, biomasses and diversity indices from combined layers (expressed per surface area). Environmental variables have been analyzed through a preliminary Principal Components Analysis (PCA) to visualize the differences between habitats based on these variables. In a subsequent step copepods, other meiofauna taxa (ostracods, foraminifers and polychaetes) and feeding types of nematodes were compared with BrayCurtis similarity redundancy relationship analyses (RDA) made with the vegan package (Oksanen et al. 2017). The relative abundance of copepods, other meiofauna (ostracods, foraminifers and polychaetes) and different feeding types of nematodes (dependent variables) were linked to environmental variables (independent variables) that were selected after stepwise forward procedure. Multicollinearity was tested for the explanatory variables using the vif.cca function in the vegan package (values over 10 indicated collinearity; Oksanen et al. 2017). The significance of the model was tested using a two-way ANOVA.

\section{Results}

\section{Sediment grain size}

Sediment of the mudflats and seagrass beds consisted of a mixture of sand (29 to 64\%), silt (29 to $58 \%$ ) and clay (7 to $15 \%$ ), while the sandflat consisted mainly of sand (98\%) (Fig. 2). Sediments were classified as silt for mudflat MO, mudflat SR (autumn) and seagrass MO (autumn), very fine sand for 
seagrass SR, mudflat SR (spring) and seagrass MO (spring) and medium sand for sandflat SR. The mud content within the different layers of the same habitat was relatively similar, with a variation lower than $2 \%$. The sediment grain-size of mudflat MO was lower than all other habitats with a median sediment grain-size of $32 \pm 4.3 \mu \mathrm{m}$, and the grain-size of sandflat SR was higher than all other habitats with a median sediment grain-size of $407 \pm 16.3 \mu \mathrm{m}$ (Supplementary material, Appendix 3).

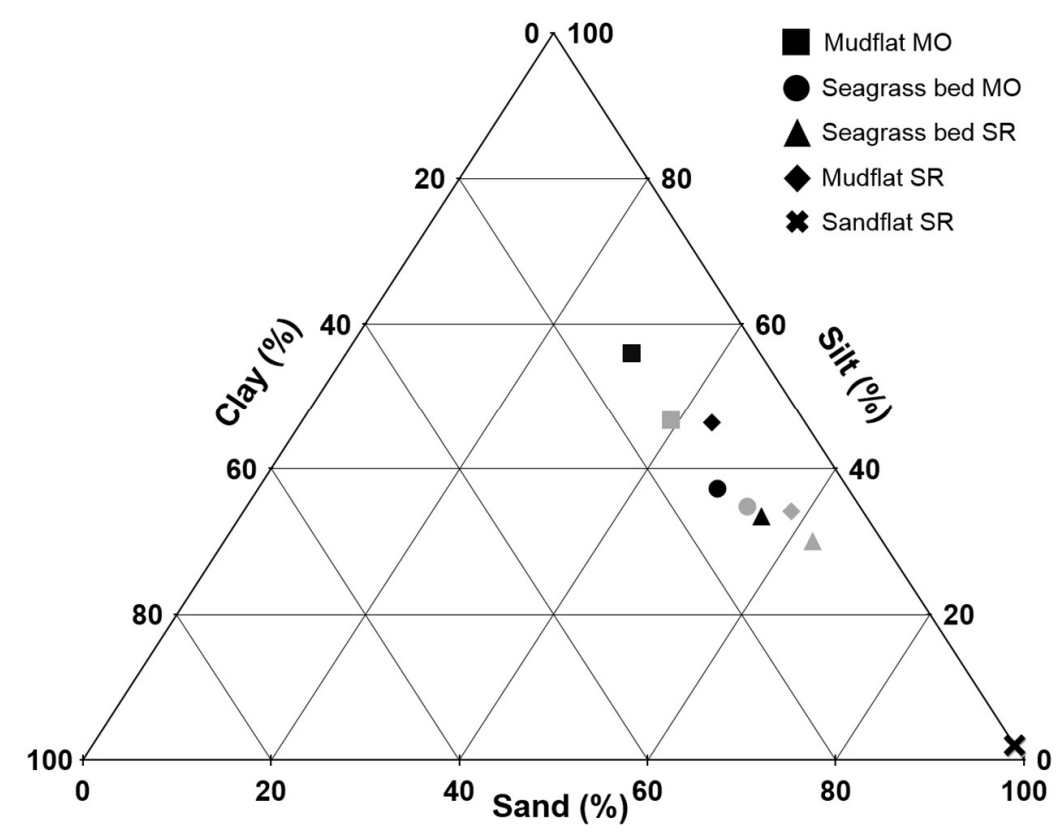

Figure 2. Ternary diagram presenting the sediment composition of the mudflats, seagrass beds and sandflat in the Marennes-Oléron Bay (MO) and the Sylt-Rømø Bight (SR) in spring (grey symbols) and autumn (black symbols). Separation by size for clay $(<3.9 \mu M)$, silty $(3.9-63 \mu M)$, and sandy $(63-2000 \mu M)$ sediment. $(n=3)$

\section{Potential food sources}

The total biomass of benthic food sources ranged from 67.4 (sandflat SR, autumn) to $447.4 \mathrm{gC} \mathrm{m}^{-2}$ (mudflat SR, spring) (Fig 3; C and E). SOM was dominant in all habitats sources with proportions ranging from 29.3 to $94.5 \%$, representing 19.8 (sandflat SR, autumn) to $290.3 \mathrm{gC} \mathrm{m}^{-2}$ (mudflat MO, autumn). Benthic microalgae were the second most dominant food source, with biomass ranging from 7.1 $\mathrm{gC} \mathrm{m}^{-2}$ (3.7\%, mudflat $\mathrm{MO}$, spring) to $70.3 \mathrm{gC} \mathrm{m}^{-2}$ (22.6\%, seagrass SR, spring). Detrital matter was found mainly in the two seagrass beds and mudflat SR with 4.3 (1.0\%, mudflat SR, spring) to $45.5 \mathrm{gC} \mathrm{m}^{-2}$ (16.7\%, seagrass bed MO, autumn). In the seagrass beds, leaves and roots were occurring with biomass ranging from $1.6\left(0.5 \%\right.$, seagrass $\mathrm{SR}$, autumn) to $15.0 \mathrm{gC} \mathrm{m}^{-2}(5.1 \%$, seagrass $\mathrm{MO}$, spring) and $0.3(0.1 \%$, seagrass $\mathrm{SR}$, autumn) to $24.4 \mathrm{gC} \mathrm{m}^{-2}$ (8.2\%, seagrass $\mathrm{MO}$, autumn). Bacteria represented the lowest biomass in all habitats with $0.6\left(0.9 \%\right.$, sandflat SR, autumn) to $20.1 \mathrm{gC} \mathrm{m}^{-2}(4.5 \%$, mudflat SR, spring). Some differences of food source biomass could be observed between the surface and the sub-surface 
layers, always with higher biomass in the surface layer when they occurred: detrital matter in mudflat SR in spring and in seagrass MO in autumn, bacteria in mudflat SR in spring, and benthic microalgae in all habitats in all seasons except for mudflat SR and sandflat SR in autumn (two-way ANOVA with Tukey post-hoc test, highest $\mathrm{p}$-value 0.032 ).

The average hierarchical cluster of dissimilarities highlighted that food source composition in the sandflat SR was different than in the other habitats (Fig. 3; A), due to the much lower biomass of SOM in sandflat SR $\left(29.2 \mathrm{gC} \mathrm{m}^{-2}\right)$ than in mudflats and seagrass beds $\left(256.6 \mathrm{gC} \mathrm{m}^{-2}\right.$; two-way ANOVA with Tukey post-hoc test, $\mathrm{p}<0.001$, Fig. $3 \mathrm{C}$ and E). Benthic microalgae biomass was much higher in sandflat SR $\left(54.2 \mathrm{gC} \mathrm{m}^{-2}\right)$ than in mudflat SR $\left(27.8 \mathrm{gC} \mathrm{m}^{-2}\right)$, mudflat MO $\left(10.5 \mathrm{gC} \mathrm{m}^{-2}\right)$ and seagrass MO $(22.6 \mathrm{gC}$ $\mathrm{m}^{-2}$, two-way ANOVA with Tukey post-hoc test, $\mathrm{p}<0.001$ ). Food source composition in both mudflats and both seagrass beds of the two bays appeared to be similar as highlighted by the clustering but some variations could be pointed out based on two-way ANOVA. Biomass of bacteria in spring was higher in mudflat SR $\left(13.5 \mathrm{gC} \mathrm{m}^{-2}\right)$ compared to mudflat MO $\left(3.9 \mathrm{gC} \mathrm{m}^{-2}\right)$, seagrass $\mathrm{MO}\left(4.2 \mathrm{gC} \mathrm{m}^{-2}\right)$, seagrass $\mathrm{SR}$ $\left(6.9 \mathrm{gC} \mathrm{m}^{-2}\right)$ and sandflat SR $\left(1.8 \mathrm{gC} \mathrm{m}^{-2}\right.$, two-way ANOVA with Tukey post-hoc test, $\left.\mathrm{p}<0.001\right)$. The presence of detrital matter in mudflat SR versus its absence in mudflat MO discriminated both mudflats as well. Lastly, biomass of leaves and roots in spring were higher in the Marennes-Oléron Bay $\left(39.4 \mathrm{gC} \mathrm{m}^{-2}\right)$ compared to the Sylt-Rømø Bight $\left(6.4 \mathrm{gC} \mathrm{m}^{-2}\right.$, two-way ANOVA with Tukey post-hoc test, $\left.\mathrm{p}<0.001\right)$.

Some differences occurred at the seasonal scale as well, with higher biomass of primary producers in spring when a difference occurred. Such a pattern was observed for benthic microalgae in sandflat SR, seagrass SR and seagrass MO, and for seagrass leaves in seagrass bed MO (two-way ANOVA with Tukey post-hoc test, $\mathrm{p}<0.001$ ). Bacteria biomass of mudflat SR and seagrass SR were also higher in spring compared to autumn (two-way ANOVA followed by Tukey post-hoc test, $\mathrm{p}<0.001$ ). About detrital matter, seasonal changes followed an opposite pattern when they occurred, with an increase in biomass of detritus from spring to autumn in mudflat SR and seagrass MO (two-way ANOVA with Tukey post-hoc test, $\mathrm{p}<0.001$ ). SOM biomass was stable between spring and autumn (two-way ANOVA with Tukey post-hoc test, lowest p-value 0.44).

Regarding quality of potential food sources in the different habitats, they varied from being partly detrital in sandflat SR (57 to 63\%) to being almost completely made out of detrital matter in mudflat MO (from 93 to 99\%). Carbon: chlorophyll $a$ (C:chl $a$ ) ratios of SOM were higher in mudflat MO (1201.4), mudflat SR (681.8) and seagrass MO (504.6) compared to seagrass SR (221.4) and sandflat SR (72.3; two-way ANOVA with Tukey post-hoc test, $\mathrm{p}<0.001$, Table 1). SOM had much higher C:chl $a$ ratios in the sub-surface layer than in the surface layer (two-way ANOVA with Tukey post-hoc test, $\mathrm{p}<0.001$ ). Variation in C:chl $a$ ratios between spring and autumn were not observed (two-way ANOVA, lowest p- 
value 0.33 , Table 1). Proportions of SOM that were originating from fresh microalgae (i.e.

279 microphytobenthos and trapped phytoplankton) ranged from 3.6 (mudflat MO, spring) to 71.1\% (sandflat

280 SR, autumn, Table 1). These proportions were much higher in sandflat SR (66.6\%) and seagrass SR (22.0\%) than in mudflat SR (7.0\%) and mudflat MO (4.0\%, two-way ANOVA with Tukey post-hoc test, Table 1). Quantities of SPOM ranged between 0.32 and $0.54 \mathrm{gC} \mathrm{L}^{-1}$. Minor variations between habitats observed within SPOM are reported in the supplementary material (Appendix 4).

Table 1. Carbon: chlorophyll $a$ ratios (mean \pm standard deviation, $n=3$ ) and percentage of carbon originating from fresh microalgae (mean \pm standard deviation, $\%, n=3$ ) in sediment organic matter (SOM) in the mudflats, seagrass beds and sandflat in the Marennes-Oléron Bay (MO) and the Sylt-Rømø Bight (SR) in spring and autumn. Letters displayed after mean values indicated grouping of similar samples (two-way ANOVA with Tukey post-hoc tests, $p<0.05$ ).

\begin{tabular}{lcccc}
\hline & \multicolumn{2}{c}{ Carbon: chlorophyll $\boldsymbol{a}$ ratio } & $\begin{array}{c}\text { Carbon of SOM originating from } \\
\text { fresh microalgae }\end{array}$ \\
\cline { 2 - 5 } & \multicolumn{4}{c}{$\%$} \\
\hline Habitat & Spring & Autumn & Spring & Autumn \\
\hline Mudflat MO & $1314.3^{\mathrm{E}} \pm 35.3$ & $1088.5^{\mathrm{D}} \pm 166.2$ & $3.6^{\mathrm{A}} \pm 0.1$ & $4.4^{\mathrm{A}} \pm 0.7$ \\
Mudflat SR & $643.9^{\mathrm{C}} \pm 60.1$ & $719.7^{\mathrm{C}} \pm 60.6$ & $7.4^{\mathrm{A}} \pm 0.7$ & $6.6^{\mathrm{A}} \pm 0.6$ \\
Seagrass MO & $389.2^{\mathrm{B}} \pm 47.5$ & $619.9^{\mathrm{C}} \pm 47.6$ & $12.4^{\mathrm{AB}} \pm 1.4$ & $7.7^{\mathrm{A}} \pm 0.6$ \\
Seagrass SR & $193.9^{\mathrm{A}} \pm 14.3$ & $249.0^{\mathrm{AB}} \pm 29.8$ & $24.6^{\mathrm{C}} \pm 1.8$ & $19.3^{\mathrm{BC}} \pm 2.4$ \\
Sandflat SR & $76.8^{\mathrm{A}} \pm 2.2$ & $67.8^{\mathrm{A}} \pm 9.1$ & $62.0^{\mathrm{D}} \pm 1.7$ & $71.1^{\mathrm{D}} \pm 9.8$ \\
\hline
\end{tabular}



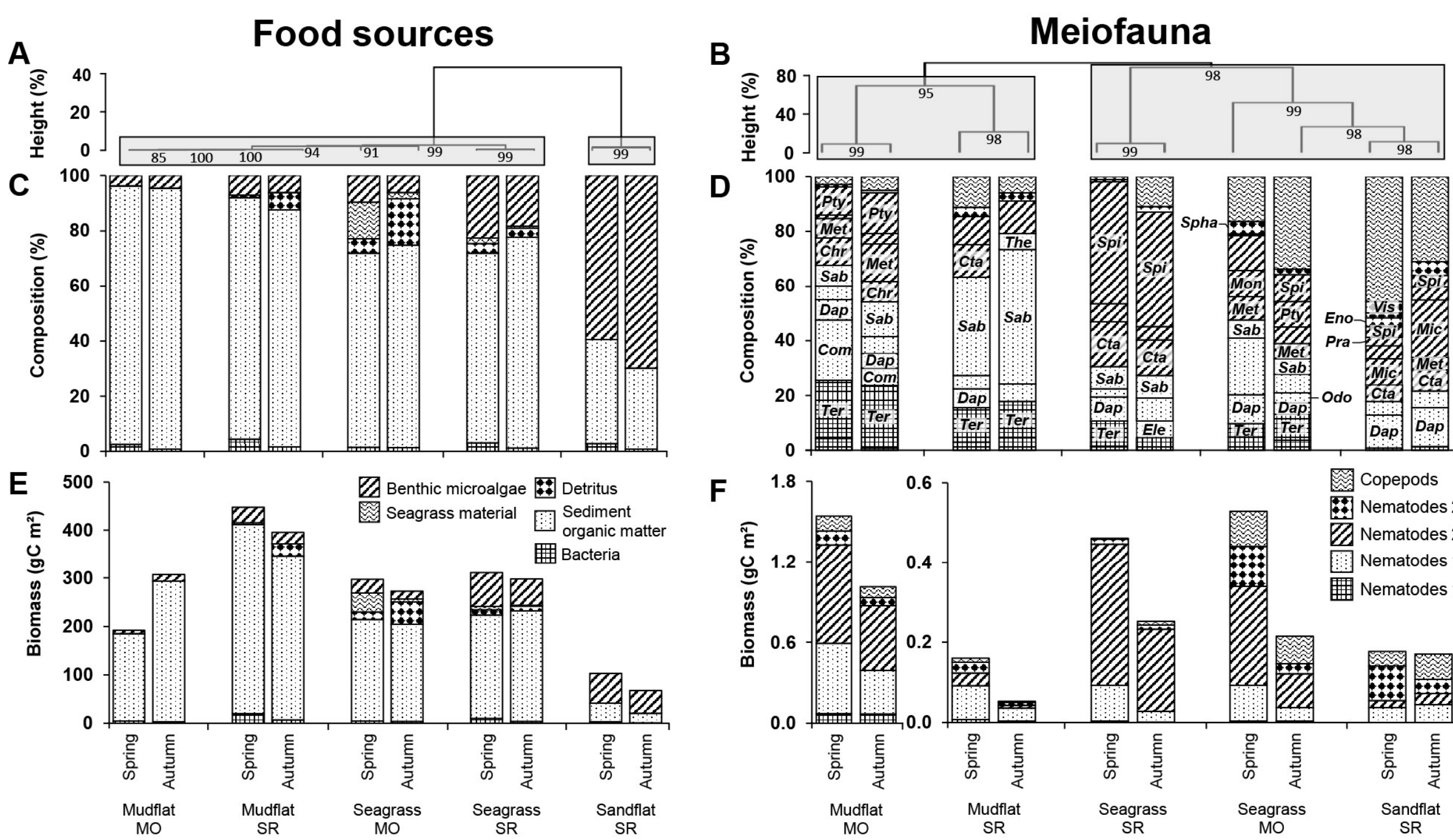
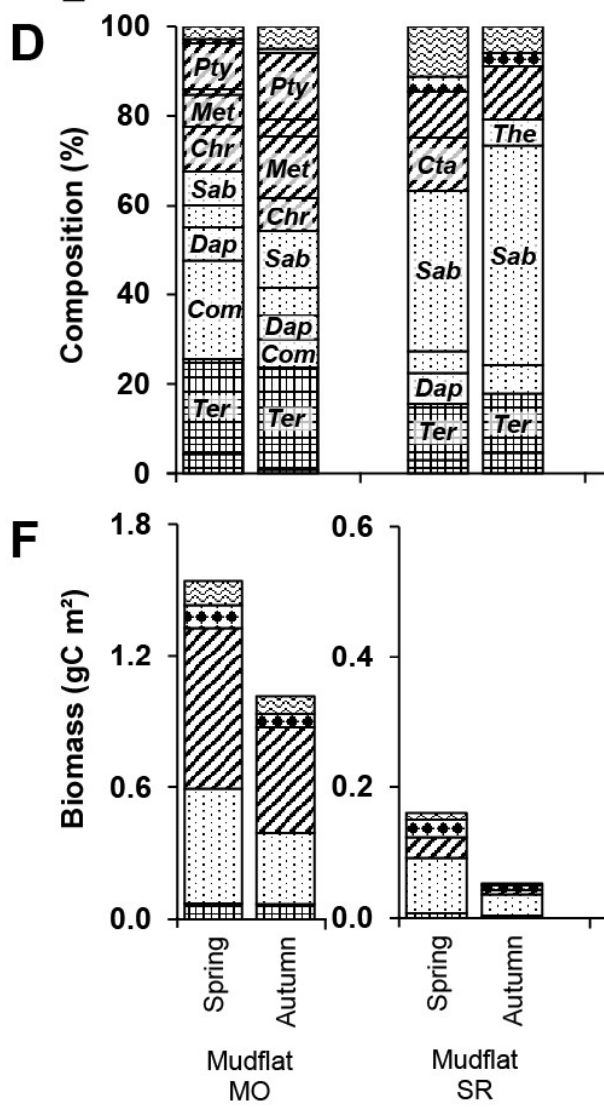

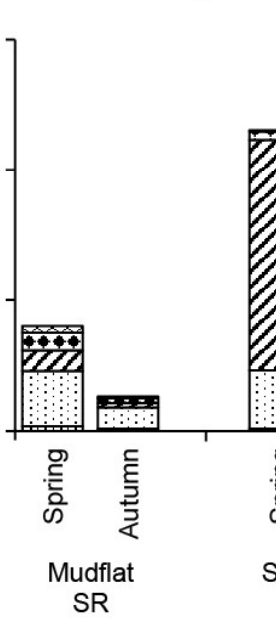

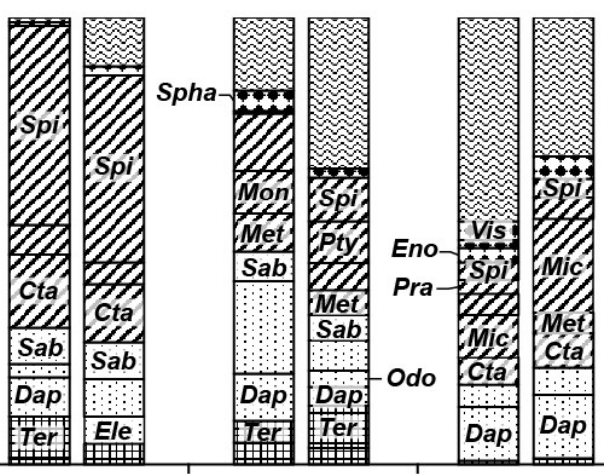

Copepods

1. Nematodes 2B

$\square$ Nematodes $2 A$

Nematodes $1 \mathrm{~B}$

㤟 Nematodes 1A

Figure 3. Composition of potential benthic food sources for meiofauna and of meiofauna in the mudflats, seagrass beds and sandflat in the Marennes-Oléron Bay (MO) and the Sylt-Rømø Bight (SR) in spring and autumn. A) Hierarchical average cluster of dissimilarity for the proportional composition of potential food sources. B) Hierarchical average cluster of dissimilarity for proportional composition of meiofauna (nematodes and benthic copepods). Approximately unbiased (AU) probability values (p-values) by multiscale bootstrap resampling are under each node and clusters (AU >=95\%) are highlighted with grey rectangles. C) Proportional composition of potential food sources. D) 
Proportional composition of benthic copepods and trophic groups of nematodes. Trophic groups of genera with relative abundance $>5 \%$ are displayed. E) Biomass of potential food sources. F) Biomass of benthic copepods and trophic groups of nematodes. Selective deposit feeders $=1 \mathrm{~A}$, non-selective deposit feeders $=1 \mathrm{~B}$, epigrowth feeders $=2 \mathrm{~A}$ and omnivores/predators $=2 \mathrm{~B}($ Wieser 1953). Abbreviations: $\mathrm{Chr}=$ Chromadora, $\mathrm{Cta}=$ Chromadorita, Com $=$ Comesa, Dap $=$ Daptonema, Ele $=$ Eleutherolaimus, Eno $=$ Enoplolaimus, Met $=$ Metachromadora, Mic $=$ Microlaimus, Mon = Monoposthia, Odo = Odontophora, Pra $=$ Praeacanthonchus, Pty $=$ Ptycholaimellus, $\mathrm{Sab}=$ Sabatieria, Spha $=$ Sphaerolaimus, Spi $=$ Spirinia, Ter $=$ Terschellingia, The $=$ Theristus, Vis $=$ Viscosia.$(n=3)$

\section{Meiofauna community structure}

The meiofauna community was dominated by nematodes with relative abundance ranging from 41.7\% (sandflat SR, surface layer, spring) to 100\% (mudflat MO, sub-surface layer, spring), except for the surface layer of sandflat SR where copepods dominated (55.5\%, Fig. 4). Four other meiofauna taxa occurred in the different habitats: copepods ( 0 to $55.5 \%)$, foraminifera ( 0 to $7.4 \%$ ), polychaetes ( 0 to $5.3 \%$ ), and ostracods ( 0 to $0.4 \%$ ). Total meiofauna density was higher in the surface layer than in the subsurface layer in all habitats (two-way ANOVA with Tukey post-hoc test, highest $p$-value 0.033). Mean meiofaunal density of both layers combined ranged from $1.7 * 10^{5}$ ind. $\mathrm{m}^{-2}$ (mudflat SR, autumn) to $3.4 * 10^{6}$ ind. $\mathrm{m}^{-2}$ (mudflat MO, autumn, Appendix 5). Meiofauna densities (both layers combined) were similar between spring and autumn, except in seagrass SR where densities were higher in spring (two-way ANOVA with Tukey post-hoc test, highest p-value 0.020, Table 2).

Total biomass of nematodes (both layers combined) ranged from $0.053 \mathrm{gC} \mathrm{m}^{-2}\left(1.6^{*} 10^{5}\right.$ ind. $\mathrm{m}^{-2}$, mudflat $\mathrm{SR}$, autumn) to $1.541 \mathrm{gC} \mathrm{m}^{-2}\left(2.9 * 10^{6}\right.$ ind. $\mathrm{m}^{-2}$, mudflat $\mathrm{MO}$, spring, Fig. $\left.3 \mathrm{~F}\right)$. Nematode density and biomass were higher in surface layers than in the sub-surface layers (two-way ANOVA with Tukey post-hoc test, highest p-value 0.042 ). Nematodes from the surface layers dominated the contribution to the total biomass in all habitats, with lowest proportions in seagrass SR (54.0\%) and mudflat SR (55.4\%) and higher proportions in sandflat SR (82.3\%), mudflat MO (83.3\%) and seagrass SR (95.7\%). At the habitat scale, nematode density and biomass were much higher in mudflat MO (density: $3.0^{*} 10^{6}$ ind. $\mathrm{m}^{-2}$; biomass: $1.257 \mathrm{gC} \mathrm{m}^{-2}$ ) than in all other habitats (two-way ANOVA with Tukey post-hoc test, $\mathrm{p}<0.001$, Table 2, Appendix 5). Nematode biomass in the seagrass beds ranged from 0.146 (seagrass MO, autumn) to $0.459 \mathrm{gC} \mathrm{m}^{-2}$ (seagrass SR, spring). Nematode biomass of the mudflat SR and sandflat SR ranged from 0.054 (mudflat $\mathrm{SR}$, autumn) to $0.150 \mathrm{gC} \mathrm{m}^{-2}$ (mudflat $\mathrm{SR}$, spring). Some temporal variations occurred as well, with higher nematode densities in spring in seagrass SR and higher nematode biomass in spring in mudflat MO (two-way ANOVA with Tukey post-hoc test, highest p-value 0.005, Table 2).

Total biomass of benthic copepods, which were merely present in the surface layers, ranged from $0.003 \mathrm{gC} \mathrm{m}^{-2}\left(1.0^{*} 10^{4}\right.$ ind. $\mathrm{m}^{-2}$, mudflat $\mathrm{SR}$, autumn) to $0.110 \mathrm{gC} \mathrm{m}^{-2}\left(1.7^{*} 10^{5}\right.$ ind. $\mathrm{m}^{-2}$, mudflat $\mathrm{MO}$, 
spring, Fig. 3F). Copepod biomass of the mudflat $\mathrm{MO}\left(0.095 \mathrm{gC} \mathrm{m}^{-2}\right)$ was much higher than in the mudflat SR $\left(0.006 \mathrm{gC} \mathrm{m}^{-2}\right)$, while copepod density was higher in the seagrass MO than in the seagrass SR and mudflat SR (two-way ANOVA with Tukey post-hoc test, $\mathrm{p}<0.001$ ). Densities and biomass of benthic copepods were similar in spring and autumn (two-way ANOVA with Tukey post-hoc test, lowest p-value 0.178, Table 2).

Table 2. Results of the two-way ANOVA for differences in total meiofauna, nematode, and benthic copepod density

335 and nematode and benthic copepod biomass across habitats and seasons.

\begin{tabular}{lccccccc}
\hline Source & \multicolumn{3}{c}{ Total meiofauna } & \multicolumn{2}{c}{ Nematodes } & \multicolumn{2}{c}{ Benthic copepods } \\
\hline \multicolumn{1}{c}{ df } & F-ratio & $\boldsymbol{P}>\mathbf{F}$ & F-ratio & $\boldsymbol{P}>\mathbf{F}$ & F-ratio & $\boldsymbol{P}>$ F \\
\hline Density & & & & & & & \\
Habitat & 4 & 363.0 & $<\mathbf{0 . 0 0 1}$ & 385.8 & $<\mathbf{0 . 0 0 1}$ & 12.7 & $<\mathbf{0 . 0 0 1}$ \\
Season & 1 & 6.3 & $\mathbf{0 . 0 2 0}$ & 9.6 & $\mathbf{0 . 0 0 5}$ & 1.9 & 0.178 \\
Habitat:season & 4 & 8.8 & $<\mathbf{0 . 0 0 1}$ & 9.1 & $<\mathbf{0 . 0 0 1}$ & 2.8 & 0.052 \\
Error & 20 & & & & & & \\
\hline
\end{tabular}

\section{Biomass}

$\begin{array}{lccccc}\text { Habitat } & 4 & 216.2 & <\mathbf{0 . 0 0 1} & 29.01 & <\mathbf{0 . 0 0 1} \\ \text { Season } & 1 & 34.5 & <\mathbf{0 . 0 0 1} & 0.47 & 0.503 \\ \text { Habitat:season } & 4 & 11.7 & <\mathbf{0 . 0 0 1} & 2.14 & 0.113\end{array}$

Error 40

$\overline{\mathrm{df}}=$ degree of freedom; $\mathrm{F}=\mathrm{F}$ statistic; $P=$ probability. Values in bold indicate a significant difference $(\alpha \leq 0.05)$

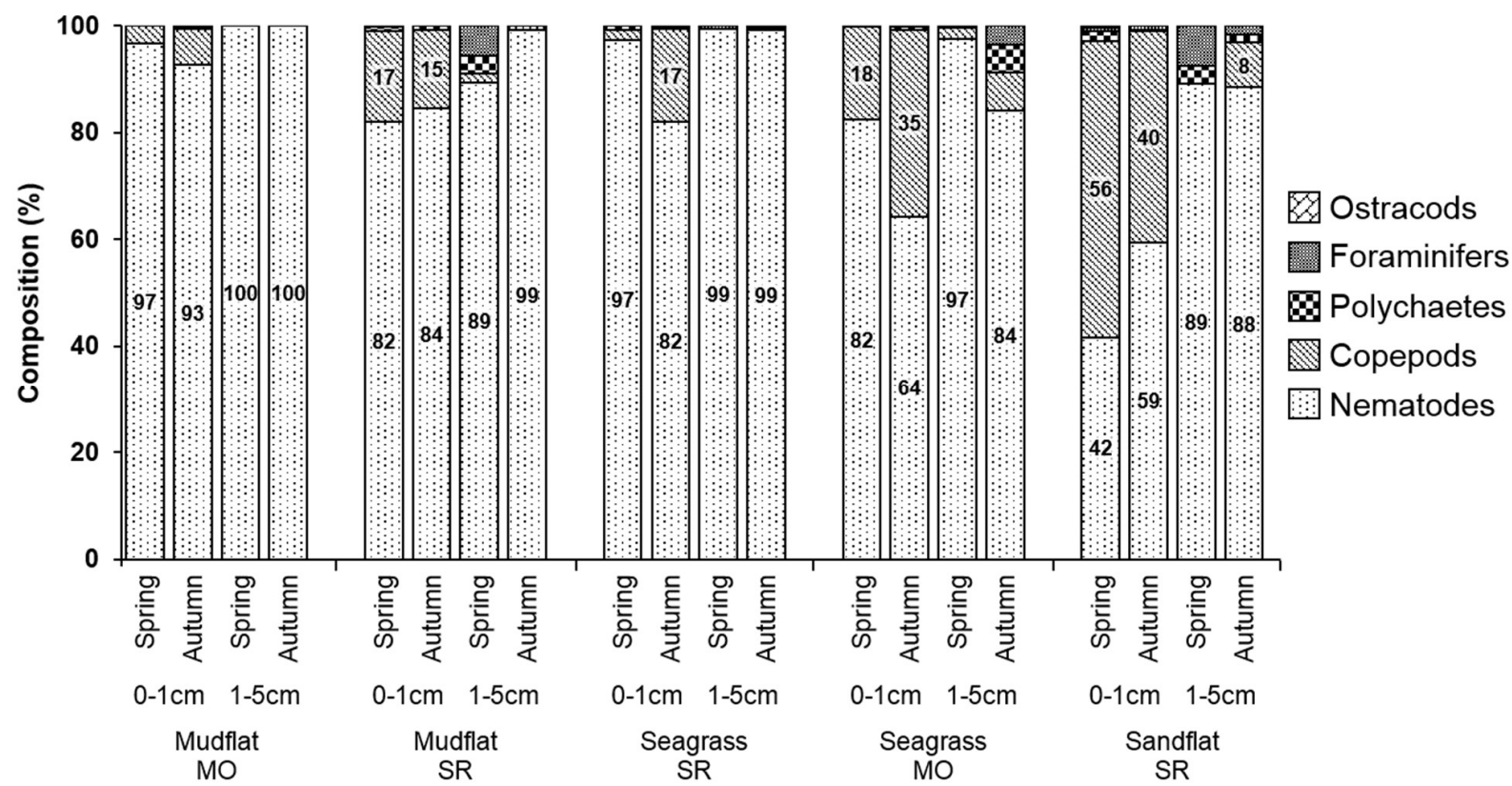


Figure 4. Proportional composition of meiofauna in the mudflats, seagrass beds and sandflat in the MarennesOléron Bay (MO) and the Sylt-Rømø Bight (SR) in spring and autumn and in each sediment layer $(0-1 \mathrm{~cm} / 1-5 \mathrm{~cm})$. Densities $(\%)$ are indicated when $>7.5 \%$. $(n=3)$

\section{Nematode community structure}

Five thousand four hundred nematodes were determined at genus and/or species level. A total of 139 species, belonging to 65 genera and 20 families were found at the five habitats in both the MarennesOléron Bay and the Sylt-Rømø Bight. Eight genera represented 70\% of the community in the surface layer of all habitats combined: Daptonema (1B, 18\%), Chromadorita (2A, 10\%), Metachromadora (2A, 10\%), Sabatieria (1B, 10\%), Ptycholaimellus (2A, 7\%), Spirinia (2A, 6\%), Terschellingia (1A, 5\%), and Praeacanthonchus (2A, 4\%). Four genera represented 70\% of the community in the sub-surface layer of all habitats combined: Terschellingia (1A, 28\%), Sabatieria (1B, 25\%), Spirinia (2A, 13\%), and Metachromadora (2A, 6\%). The surface layer had a higher number of genera (from 3 to 9 genera, mean: 5.8 ) that represented $75 \%$ of the community compared to the sub-surface layer (from 2 to 9 genera, mean: 3.4) for all habitats. The ten most dominant genera per habitat, season and sediment layer are presented in the supplementary material (Appendix 6). Species richness varied from 8 to 28, Hill's diversity from 2.3 to 19.1 , and species evenness from 0.41 to 0.88 (Table 3). Species richness, diversity and evenness decreased with depth at all habitats (two-way ANOVA, $p<0.001$, Table 4). Species richness and evenness were higher at the seagrass MO than at the mudflat SR and the seagrass SR (two-way ANOVA with Tukey post-hoc test, $\mathrm{p}<0.001)$. Hills diversity was higher at the seagrass MO than at all other habitats (two-way ANOVA with Tukey post-hoc test, $\mathrm{p}<0.001$ ). There was no difference in diversity and evenness between seasons (two-way ANOVA, lowest p-value 0.126, Table 4).

Table 3. Number of nematode genera, Hill's diversity $\left(N_{l}\right)$, and species evenness $\left(J^{\prime}\right)$ in the mudflats, seagrass beds and sandflat in the Marennes-Oléron Bay (MO) and the Sylt-Rømø Bight (SR) in spring and autumn. $(n=3)$

\begin{tabular}{|c|c|c|c|c|c|}
\hline & Mudflat MO & Mudflat SR & Seagrass SR & Seagrass MO & Sandflat SR \\
\hline & Spring Autumn & Spring Autumn & Spring Autumn & Spring Autumn & Spring Autumn \\
\hline Layer (in cm) & $\begin{array}{llll}0-1 & 1-5 & 0-1 & 1-5\end{array}$ & $\begin{array}{llll}0-1 & 1-5 & 0-1 & 1-5\end{array}$ & $\begin{array}{llll}0-1 & 1-5 & 0-1 & 1-5\end{array}$ & $\begin{array}{llll}0-1 & 1-5 & 0-1 & 1-5\end{array}$ & $\begin{array}{llll}0-1 & 1-5 & 0-1 & 1-5\end{array}$ \\
\hline Species richness & $\begin{array}{llll}22 & 11 & 21 & 13\end{array}$ & $\begin{array}{llll}23 & 12 & 15 & 13\end{array}$ & $\begin{array}{llll}16 & 11 & 16 & 12\end{array}$ & $\begin{array}{llll}24 & 19 & 23 & 14\end{array}$ & $\begin{array}{llll}20 & 12 & 21 & 18\end{array}$ \\
\hline Hill's diversity $\left(N_{l}\right)$ & $\begin{array}{llll}14 & 5 & 12 & 6\end{array}$ & 134 & 6 & $\begin{array}{llll}15 & 12 & 14 & 8\end{array}$ & 116 \\
\hline Species evenness $\left(J^{\prime}\right)$ & $\begin{array}{llll}0.9 & 0.6 & 0.8 & 0.7\end{array}$ & $\begin{array}{llll}0.8 & 0.6 & 0.8 & 0.6\end{array}$ & $\begin{array}{llll}0.7 & 0.5 & 0.6 & 0.6\end{array}$ & $\begin{array}{llll}0.8 & 0.9 & 0.8 & 0.8\end{array}$ & $\begin{array}{llll}0.8 & 0.7 & 0.8 & 0.7\end{array}$ \\
\hline
\end{tabular}


Table 4. Results of the two-way ANOVA for differences in species richness, Hill's diversity $\left(N_{l}\right)$, and species evenness $\left(J^{\prime}\right)$ between habitats, sediment layers and season in the mudflats, seagrass beds and sandflat in the Marennes-Oléron Bay and the Sylt-Rømø Bight.

\begin{tabular}{lccccccc}
\hline Source & \multicolumn{3}{c}{ Species richness } & \multicolumn{2}{c}{ Hill's diversity } & \multicolumn{2}{c}{ Species evenness } \\
\cline { 2 - 8 } & df & F-ratio & $\boldsymbol{P}>$ F & F-ratio & $\boldsymbol{P}>$ F & F-ratio & $\boldsymbol{P}>$ F \\
\hline Layer & 1 & 88.3 & $<\mathbf{0 . 0 0 1}$ & 149.6 & $<\mathbf{0 . 0 0 1}$ & 55.9 & $<\mathbf{0 . 0 0 1}$ \\
Site & 4 & 11.0 & $<\mathbf{0 . 0 0 1}$ & 29.0 & $<\mathbf{0 . 0 0 1}$ & 16.2 & $<\mathbf{0 . 0 0 1}$ \\
Season & 1 & 0.1 & 0.802 & 2.4 & 0.126 & 0.0 & 1.000 \\
Layer:site & 4 & 1.5 & 0.214 & 4.75 & $\mathbf{0 . 0 0 3}$ & 4.5 & $\mathbf{0 . 0 0 5}$ \\
Layer:season & 1 & 6.4 & $\mathbf{0 . 0 1 5}$ & 3.3 & 0.078 & 0.6 & 0.452 \\
Site:season & 4 & 3.1 & $\mathbf{0 . 0 2 6}$ & 1.9 & 0.134 & 0.3 & 0.878 \\
Layer:site:season & 4 & 2.3 & 0.079 & 2.5 & 0.062 & 2.3 & 0.077 \\
Error & 38 & & & & & & \\
\hline
\end{tabular}

$\overline{\mathrm{df}}=$ degree of freedom; $\mathrm{F}=\mathrm{F}$ statistic $; P=$ probability. Values in bold indicate a significant difference $(\alpha \leq 0.05)$

Community compositions, based on proportions of benthic copepods and of trophic groups of nematodes, were similar between the two mudflats (besides the very large difference of biomass), as highlighted by the average hierarchical cluster analysis ( $p<0.05$, Fig. 3B). The sandflat SR and the two seagrass beds had similar communities as well. The difference of trophic structures between the mudflats and the other habitats was related to the higher proportions of selective deposit-feeders (1A) and of nonselective deposit-feeders (1B) in the mudflats. The mudflat $\mathrm{MO}$ was dominated by genera belonging to non-selective deposit feeders $\left(36 \%, 0.579 \mathrm{gC} \mathrm{m}^{-2}\right)$, epigrowth feeders $\left(34 \% .0 .525 \mathrm{gC} \mathrm{m}^{-2}\right)$, and selective deposit feeders $\left(25 \%, 0.071 \mathrm{gC} \mathrm{m}^{-2}\right)$ with Terschellingia $\left(1 \mathrm{~A}, 22 \%, 0.055 \mathrm{gC} \mathrm{m}^{-2}\right)$, Comesa $(1 \mathrm{~B}, 14 \%$, $0.082 \mathrm{gC} \mathrm{m}^{-2}$ ) and Ptycholaimellus (2A, 13\%, $0.048 \mathrm{gC} \mathrm{m}^{-2}$ ) being the most common genera (Fig. 3D). At the mudflat SR, the non-selective deposit feeders dominated (55\%), and the most abundant genera were Sabatieria $\left(1 \mathrm{~B}, 43 \%, 0.042 \mathrm{gC} \mathrm{m}^{-2}\right)$ and Terschellingia $\left(1 \mathrm{~A}, 13 \%, 0.004 \mathrm{gC} \mathrm{m}^{-2}\right)$. The seagrass bed SR was dominated by epigrowth feeders with the genera Spirinia $\left(2 \mathrm{~A}, 46 \%, 0.225 \mathrm{gC} \mathrm{m}^{-2}\right)$ and Chromadorita $\left(2 \mathrm{~A}, 16 \%, 0.026 \mathrm{gC} \mathrm{m}^{-2}\right)$. The seagrass bed $\mathrm{MO}$ was dominated by various genera belonging to epigrowth feeders $\left(31 \%, 0.165 \mathrm{gC} \mathrm{m}^{-2}\right)$ and non-selective deposit feeders $\left(29 \%, 0.061 \mathrm{gC} \mathrm{m}^{-2}\right)$. There, the biomass of nematodes was dominated by the epigrowth feeder genera Metachromadora $\left(7 \%, 0.035 \mathrm{gC} \mathrm{m}^{-2}\right)$. The sandflat SR was dominated by genera belonging to epigrowth feeders $\left(35 \%, 0.023 \mathrm{gC} \mathrm{m}^{-2}\right)$ and nonselective deposit feeders $\left(19 \%, 0.040 \mathrm{gC} \mathrm{m}^{-2}\right)$, with the genera Microlaimus $\left(2 \mathrm{~A}, 15 \%, 0.006 \mathrm{gC} \mathrm{m}^{-2}\right)$ and Daptonema $\left(1 \mathrm{~B}, 13 \%, 0.028 \mathrm{gC} \mathrm{m}^{-2}\right)$ being the most common. 
The PCA on the environmental variables explained $63.2 \%$ of the total variation (Axis $1: 39.9 \%$, axis 2: $23.3 \%$, Fig. 5A). Axis 1 highlights a positive relationship between SPOM, benthic microalgae and sediment grain size. At the opposite, when biomass of benthic microalgae, SPOM and sediment grain size were low, quantities of SOM were higher, as well as bacteria and detritus biomass, and carbon:chlorophyll $a$ ratios of SOM. Axis 2 demonstrates that biomass of bacteria increased with biomass of SOM, SPOM, and benthic microalgae. Sandflat SR is defined by larger sediment grain size, higher biomass of benthic microalgae and of SPOM, as highlighted on axis 1. Axis 1 also discriminates seagrass SR from mudflat SR, mudflat MO and seagrass MO (autumn), the later ones being characterized with lower biomass of benthic microalgae and SPOM and/or higher carbon:chlorophyll $a$ ratios of SOM, and higher biomass of SOM and detritus. In spring axis 2 discriminates well the mudflat and seagrass bed in the Marennes-Oléron Bay compared to the Sylt-Rømø Bight, which could be due to higher biomass of bacteria (mudflat SR) and/or benthic microalgae (seagrass SR). In terms of temporal variations, axis 1 highlights low variation in environmental variables between spring and autumn except for seagrass MO, which could be due to a significant increase in biomass of detritus from spring to autumn in this habitat. Axis 2 highlights a stronger temporal variation (Fig. 5A), especially in seagrass SR, seagrass MO and mudflat SR. For seagrass SR this could be due to a decrease in bacteria, benthic microalgae, SPOM and SOM biomass from spring to autumn, as well as an increase in detrital matter, while changes in seagrass MO may be related to opposite patterns. For mudflat SR variations could be explained by the decrease in biomass of benthic microalgae and bacteria and/or the increase in detritus from spring to autumn.

The redundancy analyses (RDA) represented $51.8 \%$ of the total variation and $81.1 \%$ of the constrained variation (Fig. 5B). Fresh seagrass material was excluded from the RDA due to collinearity after stepwise forward selection of constraints (vif.cca $>10$ ). Axis 1 explains $33.0 \%$ of the total variation and $51.8 \%$ of the constrained variation. Axis 2 explains $18.8 \%$ of the total variation and $29.4 \%$ of the constrained variation. Both axes significantly explain the model, which highlights relationships between differences of communities and environmental parameters, particularly biomass of benthic microalgae, SPOM, detritus, SOM, carbon:chlorophyll $a$ ratios and sediment grain size. Patterns highlighted by axis 1 about environmental parameters were similar as those highlighted in the PCA: there was a positive relationship between benthic microalgae and SPOM biomasses, and sediment grain size. At the opposite, when benthic microalgae, SPOM and detritus biomasses were low, the carbon:chlorophyll $a$ ratio was higher, as well as biomasses of SOM, bacteria and detritus. Differences of meiofauna trophic structure within habitats are mainly explained by sediment grain-size, carbon:chlorophyll $a$ ratio of SOM, and biomasses of SOM, SPOM, detritus, benthic microalgae, and bacteria (Fig. 5). Selective deposit feeders and non-selective deposit feeders occurred mainly within habitats where biomasses of SOM, detritus and bacteria where high (i.e. sub-surface layers of mudflat SR in both seasons, sub-surface layers of seagrass 
MO in both seasons, and sub-surface layers of mudflat MO in autumn). Epigrowth feeders dominated in habitats where benthic microalgae were an important driving factor (i.e. surface layers of mudflat MO in both seasons, sub-surface layers of mudflat MO in spring, surface and sub-surface layers of seagrass SR in both seasons, and sub-surface layers of sandflat SR in both seasons). Omnivore/predatory nematodes, benthic copepods and other meiofauna taxa occurred in habitats with high biomass of benthic microalgae and SPOM, as well as large sediment grain-size (i.e. surface and sub-surface layers of sandflat SR in both seasons and surface layers of seagrass MO in both seasons, and surface layers of mudflat SR in both seasons).

A

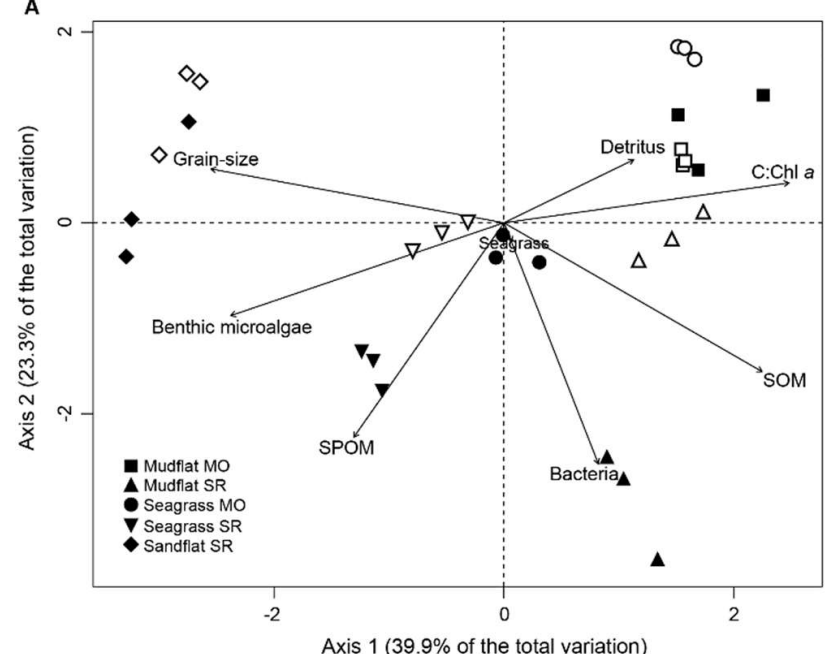

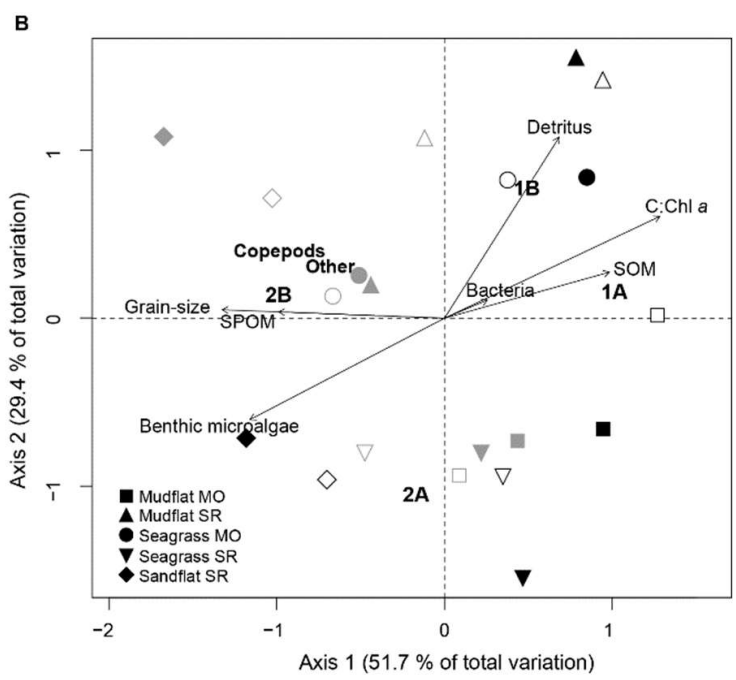

Figure 5. (A) Principal component analyses for the environmental factors (arrows) plotted for the mudflats, seagrass beds and sandflat in the Marennes-Oléron Bay (MO) and the Sylt-Rømø Bight (SR) in spring (closed symbols) and autumn (open symbols). (B) Redundancy relationship analyses of environmental factors (arrows) selected with stepwise forward procedure plotted against the different groups of meiofauna (benthic copepods, trophic groups of nematodes and other meiofauna taxa) and the surface (grey symbols) and sub-surface layers (black symbols) of the mudflats, seagrass beds and sandflat in the Marennes-Oléron Bay (MO) and the Sylt-Rømø Bight (SR) in spring (closed symbols) and autumn (open symbols). Abbreviations: OTHER = other meiofauna (i.e. polychaetes, foraminifers, and ostracods); SPOM = suspended particulate organic matter; $\mathrm{SOM}=$ sediment organic matter; $1 \mathrm{~A}=$ nematodes, selective deposit feeders; $1 \mathrm{~B}=$ nematodes, non-selective deposit feeders; $2 \mathrm{~A}=$ nematodes, epigrowth feeders; $2 \mathrm{~B}=$ nematodes, omnivores/predators.

A regression using nematode feeding type data from all habitats highlighted that the ratios between densities of epigrowth feeders and densities of non-selective deposit feeders increased when benthic microalgae biomass increased $\left(\mathrm{F}[1,8]=10.4, \mathrm{p}=0.01, \mathrm{r}^{2}=0.61\right.$, Fig. 6). The relative abundance of selective deposit feeders was positively correlated to the ratio between biomass of fresh organic material 

detritus) $\left(\mathrm{F}[1,8]=23.1, \mathrm{p}<0.01, \mathrm{r}^{2}=0.74\right.$, Fig. 7).

446

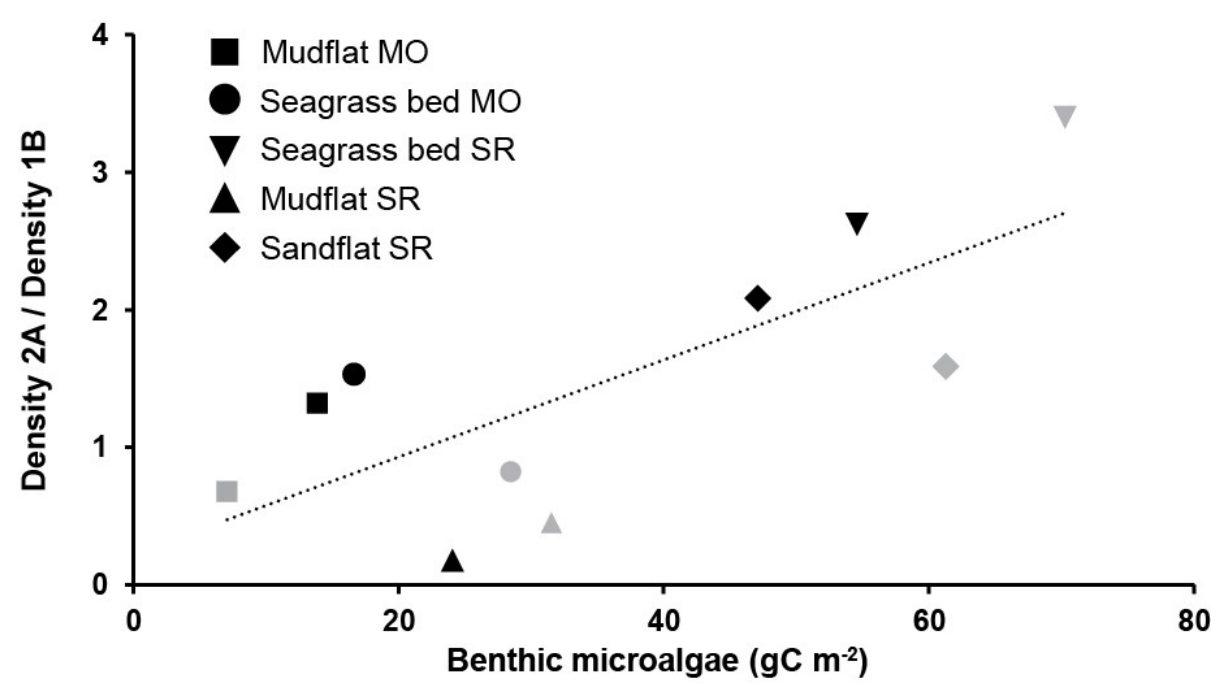

Figure 6 Relationship between the biomass of benthic microalgae and the ratio between densities of epigrowth feeders (2A) and densities of non-selective deposit feeders (1B) in the mudflats, seagrass beds and sandflat in the Marennes-Oléron Bay (MO) and the Sylt-Rømø Bight (SR) in spring (grey symbols) and autumn (black symbols). $(n=3)$

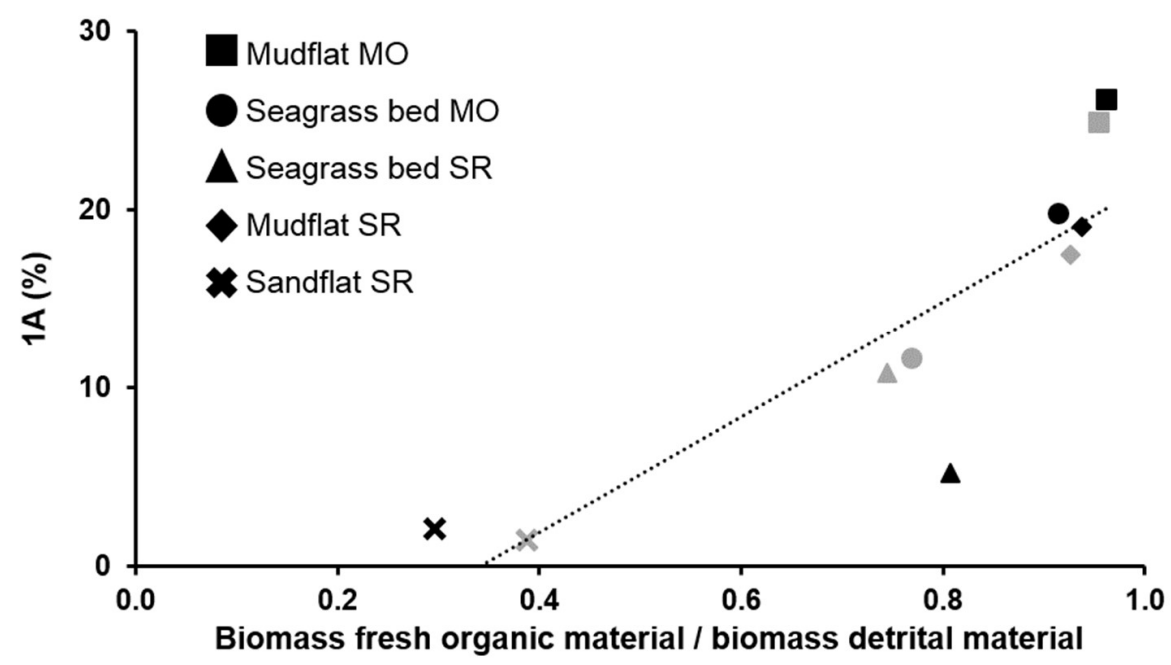

Figure 7. Relationship between the ratio of fresh organic material to detrital material and the relative abundance of selective deposit feeders (1A) in the mudflats, seagrass beds and sandflats in the Marennes-Oléron Bay (MO) and the Sylt-Rømø Bight (SR) in spring (grey symbols) and autumn (black symbols). ( $n=3$ )

\section{Discussion}

\section{Habitat description}


The different habitats compared in this study are characterized by a broad range of abiotic and biotic factors. This provides a good framework to determine how changes in these parameters, particularly potential food resources, may influence meiofauna community structure. Biomass of benthic microalgae was much higher in habitats with a larger sediment grain size (sandflat SR and seagrass SR) as already observed in the Marennes-Oléron Bay (Guarini et al. 1998), and benthic microalgae therefore represented a much higher proportion of the SOM in these habitats. This pattern is quite unusual, as habitats with large sediment grain size generally support less microphytobenthos biomass than habitats with small sediment grain size (Cammen 1991; de Jong and de Jonge 1995). Estimations of benthic microalgae biomass were based on chlorophyll $a$ measurements and therefore included trapped fresh phytoplankton. Trapped phytoplankton represents a lower proportion of fresh microalgae material than benthic microphytobenthos, although some variations can occur depending on seasons and locations (Asmus 1983; Lebreton et al. 2012). Microphytobenthos community structure and its production may change as well depending on habitats: muddy sediments are usually dominated by large epipelic diatoms (Thornton et al. 2002; Azovsky et al. 2004) whereas small epipsammic diatoms are the main taxa in sandy habitats (Asmus and Bauerfeind 1994; Azovsky et al. 2004). Benthic microalgae production can be very high in muddy sediments (i.e. $372 \mathrm{gC} \mathrm{m}^{-}$ $2 \mathrm{yr}^{-1}$ in mudflat MO) (Pinckney and Zingmark 1993; Leguerrier et al. 2003) and, under favorable conditions, epipelic diatoms can double their standing stock on a daily basis (Underwood and Paterson 1993). All these changes of biomass, community structure and production rates likely affect the use of this food resource by meiofauna.

Biomass of SOM was much lower in sandflat SR than in seagrass beds and mudflats. This is likely related to the high benthic microalgae production in bare mudflats (MacIntyre et al. 1996) and to the smaller sediment grain size in mudflats and seagrass beds (Bergamaschi et al. 1997). A decrease in sediment grain size generally leads to an increase in SOM (Bergamaschi et al. 1997) as fine particles enhance adsorption of organic compounds (Mayer 1994). Decrease of sediment grain size is also associated to lower hydrodynamics which increases sedimentation of organic matter particles (Frontalini et al. 2014) and of finer sediment. The presence of seagrass beds, reducing hydrodynamics and enhancing sedimentation as well (Leduc et al. 2009), also likely increased the load of SOM. As a result, even if SPOM was relatively similar between habitats, the presence of meadows may influence the biomass and the nature of the organic matter available to meiofauna between unvegetated and vegetated habitats (Machás and Santos 1999). The quality of the organic matter available to consumers was also correlated with sediment grain size, with SOM dominated by fresh organic matter in the sandflat and being of much lower quality in habitats made of fine sediments (seagrass bed and mudflats), where loads of detrital matter were higher. 
Loads of detritus were high in seagrass beds, the largest ones being measured in seagrass $\mathrm{MO}$, probably due to the much higher biomass of seagrass roots in this habitat compared to seagrass SR. The higher load of detrital matter in mudflat SR compared to mudflat MO is much likely related to the proximity between the mudflat and the seagrass bed in the Sylt-Rømø Bight, highlighting that seagrass material can be exported to bare systems. The presence of seagrass in intertidal systems may also indirectly affect the composition of the detrital organic matter available to meiofauna and meiofauna distribution in the sediment (Marbà et al. 2006). The complex root structure of seagrass beds indeed plays a role for the amount of fine particles and detritus associated with the shallow oxic zone in vegetated sediments (Wetzel et al. 2001), as well as in the release of oxygen and dissolved organic matter by the roots (Pedersen et al. 1998). Nevertheless, seagrass material is generally poorly used by most of the consumers as fresh or as detrital material (Danovaro 1996; Vizzini et al. 2002). The presence of seagrass and detritus as well as smaller sediment grain size also affected the abundance of bacteria within the studied habitats. Much lower biomass of bacteria was observed in habitats with lower quantities of detrital matter and SOM and in habitats with coarser sediment (i.e. sandflat), likely due to the reduced surface for bacteria colonization (Dale 1974; Mayer 1994).

\section{Meiofauna community structure: spatial and temporal variations}

Meiofauna density and biomass varied highly within habitats and ecosystems, with lowest and highest values observed in mudflat SR (density: $0.17^{*} 10^{6}$ ind. $\mathrm{m}^{-2}$, biomass: $0.057 \mathrm{gC} \mathrm{m}^{-2}$ ) and mudflat MO (density: $3.36 * 10^{6}$ ind. $\mathrm{m}^{-2}$, biomass: $1.598 \mathrm{gC} \mathrm{m}^{-2}$ ), respectively. Meiofauna in all habitats were dominated by nematodes, followed by benthic copepods, as typically observed in intertidal habitats (Armonies and Hellwig-Armonies 1987; Rzeznik-Orignac et al. 2003; Leduc and Probert 2011). Data comparisons (Table 5) highlight that density and biomass of nematodes and benthic copepods measured in this study are in the range of those previously measured but, more generally, that these values can be highly variable between different soft-bottom habitats as well as within similar habitats (Heip et al. 1985; Castel et al. 1989; Kotwicki et al. 2005b).

In terms of community structure, proportions of benthic copepods increased from habitats with a lower complexity (mudflats: $6.2 \%$ ) to habitats with a higher complexity caused by a higher seagrass biomass (seagrass beds: $15.5 \%$ ) or by larger sediment grain size (sandflat: $38.4 \%$ ). Larger proportions of copepods in the sandflat could be explained by a higher feeding efficiency in sandier sediment, probably due to a better accessibility to benthic microalgae and a better ability of these grazers to move in sand (De Troch et al. 2006). Higher proportions of benthic copepods in seagrass bed MO may be related to a more developed seagrass bed and therefore a more complex habitat, providing a larger diversity of ecological niches (Ndaro and Olafsson 1999; De Troch et al. 2001). The presence and development stage of seagrass 
beds also affected nematode diversity as species richness was higher in the most dense seagrass bed (Marennes-Oléron) between the two studied ones. Hill's diversity was also higher in seagrass MO than in all other habitats, which could be partially linked to habitat complexity as well (Austen et al. 1998; Steyaert et al. 2003; Giere 2009). Proportions of omnivore/predatory nematodes increased as well when complexity increased due to larger sediment grain size as previously observed in sandflats of several other coastal ecosystems (Warwick 1971; Steyaert et al. 2003). This could be explained by the increase of foraging efficiency of predators with an increase in sediment grain size (Gallucci et al. 2005).

If some patterns could be observed between meiofauna community structure and habitat type, direct relationships between biomass of food sources and density and/or biomass of nematodes and benthic copepods could not be observed in this study. This is very likely related to the diversity of feeding types observed in nematodes (Moens et al. 2005b; Vafeiadou et al. 2014) and, to a lower extent, in benthic copepods (Cnudde et al. 2015), confirming the importance of approaches carried out at the scale of the feeding type, as this was done for nematodes in this study.

Within these different habitats nematode density, biomass and diversity were similar between spring and autumn, except for higher nematode density in seagrass SR and higher nematode biomass in mudflat MO in spring. No temporal variation was observed for meiofauna community structure. The lack of a clear temporal pattern between spring and autumn (Escaravage et al. 1989; Danovaro and Gambi 2002; Rzeznik-Orignac et al. 2003) could be partly explained by low temporal variation in parameters strongly defining meiofauna community structure (i.e. food sources and sediment grain size; Moens et al. 2013).

Table 5. Density (ind. $\mathrm{m}^{-2} * 10^{6}$ ) and biomass (in $\mathrm{gC} \mathrm{m}^{-2}$ and/or g dry weight $\mathrm{m}^{-2}$ ) of nematodes and benthic copepods in mudflats, seagrass beds (Zostera spp.) and sandflats from this study and from the available literature about marine soft-bottom intertidal systems. Average conversion factors used to estimate biomass in $\mathrm{gC} \mathrm{m}^{-2}$ from densities are: nematodes: $2.28^{*} 10^{6}$, benthic copepods: $3.49 * 10^{6}$, and from biomass (in $\mathrm{g}$ dry-weight $\mathrm{m}^{-2}$ ) are: nematodes: 3.26 , benthic copepods: 3.40 . Converted values are in

\begin{tabular}{|c|c|c|c|c|c|c|c|c|}
\hline \multirow{2}{*}{$\begin{array}{l}\text { Habitat } \\
\text { type }\end{array}$} & \multirow[t]{2}{*}{ Location } & \multicolumn{2}{|c|}{ Density } & \multicolumn{2}{|c|}{$\begin{array}{c}\text { Biomass } \\
\text { (g dry weight } \mathrm{m}^{-2} \text { ) }\end{array}$} & \multicolumn{2}{|c|}{$\begin{array}{l}\text { Biomass } \\
\left(\mathrm{gC} \mathrm{m}^{-2}\right)\end{array}$} & \multirow[t]{2}{*}{ Reference } \\
\hline & & Nematodes & Copepods & Nematodes & Copepods & Nematodes & Copepods & \\
\hline \multirow{7}{*}{ Mudflat } & Papanui Inlet, New Zealand & $2.1-3.2$ & $0.5-1.1$ & 0.163 & 0.125 & 0.05 & 0.04 & \multirow{7}{*}{$\begin{array}{l}\text { Leduc and Probert } 2011 \\
\text { Smidt } 1951 \\
\text { This study } \\
\text { Ellison } 1984 \\
\text { Rzeznik-Orignac et al. } 2003 \\
\text { Armonies and Hellwig- } \\
\text { Armonies } 1987 \\
\text { Warwick and Price } 1979\end{array}$} \\
\hline & Danish Wadden Sea, Denmark & 0.22 & & $0.03-0.4$ & & $0.01-0.12$ & & \\
\hline & Sylt-Rømø Bight, Germany & 0.28 & 0.03 & 0.233 & 0.015 & 0.102 & 0.006 & \\
\hline & Cornwall, U.K. & 1.1 & & & & 0.48 & & \\
\hline & Marennes-Oléron Bay, France & 2.1 & & & & 0.92 & & \\
\hline & Sylt-Rømø Bight, Germany & 2.4 & 0.07 & & & 1.05 & 0.02 & \\
\hline & Lynher estuary, U.K. & $0.8-22.9$ & & $1.4-3.4$ & & $0.43-1.49$ & & \\
\hline
\end{tabular}




\begin{tabular}{|c|c|c|c|c|c|c|c|c|}
\hline & $\begin{array}{l}\text { Marennes-Oléron Bay, France } \\
\text { Marennes-Oléron Bay, France } \\
\text { South Carolina, U.S.A. } \\
\text { European estuaries }\end{array}$ & $\begin{array}{c}3.03 \\
2.3-4.4 \\
0.13-14.5\end{array}$ & 0.13 & 6.070 & 0.346 & $\begin{array}{c}0.2-1.5 \\
1.257 \\
1.01-1.93 \\
0.06-6.35 \\
\end{array}$ & $\begin{array}{l}<0.09 \\
0.095\end{array}$ & $\begin{array}{l}\text { Pascal } 2008 \\
\text { This study } \\
\text { Sikora and Sikora } 1982 \\
\text { Soetaert et al. } 1995 \\
\end{array}$ \\
\hline \multirow{7}{*}{$\begin{array}{l}\text { Seagrass } \\
\text { bed }\end{array}$} & Papanui Inlet, New Zealand & $4.9-5.2$ & $<0.04$ & 0.480 & $<0.009$ & 0.15 & $<0.003$ & \multirow{7}{*}{$\begin{array}{l}\text { Leduc and Probert } 2011 \\
\text { This study } \\
\text { This study } \\
\text { Armonies and Hellwig- } \\
\text { Armonies } 1987 \\
\text { Castel et al. } 1989 \text {; } \\
\text { Escaravage et al. } 1989 \\
\text { Materatski et al. } 2018 \\
\text { Lebreton } 2009\end{array}$} \\
\hline & Marennes-Oléron Bay, France & 0.65 & 0.21 & 1.303 & 0.459 & 0.294 & 0.078 & \\
\hline & Sylt-Rømø Bight, Germany & 0.81 & 0.04 & 0.819 & 0.015 & 0.351 & 0.006 & \\
\hline & Sylt-Rømø Bight, Germany & 2.0 & & & & 0.88 & & \\
\hline & Arcachon Bay, France & $5.5-8.0$ & & $2.4-5.3$ & & $0.74-2.32$ & & \\
\hline & Mira estuary, Portugal & $1.8-3.3$ & & & & $0.79-1.46$ & & \\
\hline & Marennes-Oléron Bay, France & & & & & 2.75 & 0.36 & \\
\hline \multirow{6}{*}{ Sandflat } & North Sea intertidal sandflats & 0.15 & 0.11 & & & 0.07 & 0.03 & \multirow{5}{*}{$\begin{array}{l}\text { Kotwicki et al. } 2005 \text { a } \\
\text { This study } \\
\text { Castel et al. } 1989 \text {; } \\
\text { Escaravage et al. } 1989 \\
\text { Smol et al. } 1994 \\
\text { Armonies and Hellwig- } \\
\text { Armonies } 1987\end{array}$} \\
\hline & Sylt-Rømø Bight, Germany & 0.22 & 0.14 & 0.303 & 0.130 & 0.124 & 0.050 & \\
\hline & Arcachon Bay, France & $0.7-1.2$ & & $0.8-1.3$ & & $0.25-0.57$ & & \\
\hline & Oosterschelde, Netherlands & 5.0 & 0.13 & 2.0 & 0.2 & 0.61 & 0.06 & \\
\hline & Sylt-Rømø Bight, Germany & 2.3 & 3.5 & & & 1.01 & 1.00 & \\
\hline & European intertidal flats & $0.24-4.1$ & $<0.35$ & & & $0.11-1.80$ & $<0.10$ & $\begin{array}{l}\text { Hicks and Coull 1983; } \\
\text { Kotwicki et al. } 2005 b\end{array}$ \\
\hline
\end{tabular}

549 Benthic microalgae and sediment organic matter are important drivers of nematode community

550

551

552

553

554

555

556

557

558

559

560

561

562

\section{structure}

Changes in benthic microalgae biomass influenced the community structure of nematodes: relative abundance of epigrowth feeders, relying on benthic microalgae, were reduced when biomass of this food source decreased. Such a relationship between biomass of benthic microalgae and density of epigrowth feeders had already been observed in a subtidal seagrass meadow (Danovaro and Gambi 2002) and during grazing experiments (Rzeznik-Orignac and Fichet 2012). A relationship was also observed between biomass of benthic microalgae and relative abundances of benthic copepods and omnivores/predators. However, this relationship may be partly mediated by sediment grain size as benthic microalgae biomass (this study) and relative abundance of benthic copepods increase when sediment get coarser (Hicks and Coull 1983). Nevertheless, the much higher biomass of benthic microalgae in the sandflat compared to SOM suggests that consumers rely—at least partly—directly (i.e. copepods) or indirectly (i.e. omnivores/predators) on benthic microalgae in this habitat. Such a dependence to benthic microalgae as a food source has been demonstrated for benthic copepods (Leduc et al. 2009).

At a more global scale (i.e. whole meiofauna, all habitats combined), no general pattern could be observed between benthic microalgae biomass and those of nematodes and benthic copepods. Some other parameters should probably be taken into account to better consider relationships between this food resource and consumers. Benthic microalgae can indeed reach very high production rates and is a food source of high quality (Cebrián 1999). Intense grazing by meiofauna may affect benthic microalgae as well. 
The high primary production of benthic microalgae in mudflat $\mathrm{MO}\left(372 \mathrm{gC} \mathrm{m}^{-2} \mathrm{yr}^{-1}\right.$; Leguerrier et al. 2003) and high grazing pressure on this food source by the large biomass of nematodes (Blanchard 1991) could explain the lack of relationship between benthic microalgae and meiofauna biomass within these habitats. Quality is of high importance as well: Moens et al. (1999b) suggested that meiofauna migrates actively towards 'optimal' food sources. In addition to epigrowth feeders, several studies demonstrated that deposit feeders rely on microalgae (Moens and Vincx 1997; Rzeznik-Orignac et al. 2003; Vafeiadou et al. 2014) likely due to the better quality of microalgae. A relationship between density of nematodes belonging to these feeding groups and microalgae has been observed (Moens et al. 1999a). In particular, grazing experiments using ${ }^{14} \mathrm{C}$ labelled diatoms indicated the dependence of a non-selective deposit feeding nematode (Daptonema), an epigrowth feeding nematode (Metachromadora) and benthic copepods on microalgae (Rzeznik-Orignac and Fichet 2012). Buccal cavities of epigrowth feeders are appropriate for consumption of benthic microalgae, due to the presence of a dorsal tooth which is used to pierce diatoms (Wieser 1953; Moens and Vincx 1997). Vafeiadou et al. (2014), using stable isotopes, confirmed that nonselective deposit feeding nematodes, epigrowth feeding nematodes and benthic copepods can largely rely on benthic microalgae in sparsely covered seagrass beds. The non-selective deposit feeders can therefore be considered as opportunistic feeders, which may change feeding strategies depending on the availability of food sources (Moens and Vincx 1997; Rzeznik-Orignac et al. 2008). As a result, benthic microalgae are often considered as the principal food source for nematodes and benthic copepods (Moens et al. 2005a; Rzeznik-Orignac et al. 2008; Maria et al. 2012).

Benthic microalgae followed an opposite pattern than detrital material (SOM and detritus), with decreasing biomass of benthic microalgae when detrital material increased. SOM biomass was stable between spring and autumn, as well as between surface and sub-surface layers, but large variations were observed between the different habitats (i.e. much lower biomass in sandflat SR). Relative abundance of non-selective deposit feeders, closely related to detrital matter based on the RDA, decreased when biomass of SOM was lowered. Higher SOM quality in the surface sediment layers could lead to higher biomass, density and diversity of nematodes in the surface layer compared to the sub-surface layer. As a result, the important role of SOM is very likely related to its very high amount, as well as variations in quality between the studied systems. A relationship between SOM and density of non-selective deposit feeders was also recognized in a subtidal seagrass meadow (Danovaro and Gambi 2002), while a grazing experiment indicated that non-selective and selective deposit feeding nematode species assimilated predominantly SOM and bacteria (Tietjen and Lee 1977).

As a result, SOM and benthic microalgae appear to be important biotic factors driving the nematode community structure and, a fortiori, the composition of meiofauna assemblages as nematodes represent a 
601

large proportion of the meiofauna in coastal ecosystems (Armonies and Hellwig-Armonies 1987; RzeznikOrignac et al. 2003; Leduc and Probert 2011).

\section{Role of bacteria as a food source?}

Selective deposit feeders had much higher relative abundances in habitats with larger loads of detritus and SOM compared to those dominated by fresh material. In addition, multivariate analyses indicated that biomass of bacteria were higher when loads of SOM increased. These results highlight a probable relationship between bacteria biomass and relative abundance of selective deposit feeders, endorsing that consumers from this trophic group rely on bacteria (Moens and Vincx 1997), which develop on detrital particles (Day et al. 1989; Danovaro 1996), or dissolved organic matter (Moens and Vincx 1997). The use of bacteria as food resources has been confirmed by stable isotope studies demonstrating that selective deposit feeders can rely on sulfide-oxidizing bacteria (Vafeiadou et al. 2014), such specific diets being related to their small buccal cavity (Wieser 1953; Moens and Vincx 1997). The lack of direct relationship between abundances of selective deposit feeders and biomass of bacteria, as in Semprucci et al. (2010), might be due to the influence of additional abiotic parameters (i.e. oxic conditions (Jensen 1983) and sediment grain size (Steyaert et al. 2003)), the reliance of bacteria on a large diversity of substrates (Boschker et al. 2000), and high bacterial production which is only partially grazed ( $<28 \%$, Pascal et al. 2009).

Multivariate analyses demonstrated as well a relationship between relative abundances of nonselective deposit feeders and biomass of detritus and, to a lower extent, those of bacteria and SOM. Nevertheless, no direct relationship was observed between relative abundances of non-selective deposit feeders and bacteria, SOM or detritus biomass, which is likely related to the more opportunistic feeding behavior of these nematodes (Moens and Vincx 1997; Rzeznik-Orignac et al. 2008). The shape of the buccal cavity of non-selective deposit feeders allows them to rely on a much larger diversity of food sources: benthic microalgae, SOM, bacteria and seagrass detritus, as demonstrated by stable isotope studies (Rzeznik-Orignac et al. 2008; Maria et al. 2012; Vafeiadou et al. 2014) and observations of feeding behavior (Moens and Vincx 1997). Biomass of fresh seagrass matter, which varied highly between habitats in this study, could also not be linked to variations in non-selective deposit feeders. However, the lack of relation here is expected since this resource is poorly used by these nematodes, and, to a larger extent, to meiofauna in general, due to its low nutritional value and high lignocellulose content (Vizzini et al. 2002). This was confirmed by Materatski et al. (2015) who observed no changes in nematode density before and after a seagrass collapse.

\section{Effect of sediment depth on meiofauna communities: influence of oxic conditions}


Nematode and benthic copepod densities and biomasses decreased from surface to sub-surface layers in all habitats, which is a common pattern in seagrass beds and unvegetated habitats (Castel et al. 1989; Lebreton 2009; Leduc and Probert 2011). Benthic microalgae, which have the highest biomass in the surface layer, might influence the vertical distribution and migration of nematodes and benthic copepods (Moens et al. 2013), particularly nematode epigrowth feeders which specifically rely on benthic microalgae and which were very abundant in all habitats. Differences in abiotic parameters, such as oxygen depletion towards deeper layers, could affect as well the vertical distribution of meiofauna (Steyaert et al. 2003; Vanaverbeke et al. 2004), as anoxic conditions are much less favorable to nematodes and benthic copepods. Besides influencing biomass and densities, anoxic conditions affect diversity and community structure as well. Diversity of nematodes clearly decreased with depth in all the studied habitats, which was observed in other studies (Steyaert et al. 2003; Leduc and Probert 2011). Terschellingia spp. and Sabatieria spp. had a higher relative abundance in sub-surface layers than in surface layers, related to their higher tolerance regarding hypoxic conditions (Steyaert et al. 2007). Terschellingia spp. and Sabatieria spp. are also known to feed on sulfide-oxidizing bacteria that occur in these hypoxic zones (Semprucci and Balsamo 2012; Vafeiadou et al. 2014).

\section{Conclusion}

Benthic microalgae and SOM are two important drivers in the functioning of soft-bottom coastal food webs as changes in these food resources affect the two most dominant nematode trophic groups (i.e. nonselective deposit feeders, considered as more opportunistic, and epigrowth feeders, more specifically related to benthic microalgae). This is likely related to the high biomass of these food sources, as well as the quality and high production rates of benthic microalgae (MacIntyre et al. 1996; Cebrián 1999). Therefore, this study highlights the existence of some relationships between composition of food sources and the trophic structure of the meiofauna community, when studied at the scale of trophic groups. On the contrary, no clear relationship was observed between bacterial biomass and density of selective deposit feeders (bacterivores; 1A), despite a relationship between SOM biomass and relative abundances of selective deposit feeders. This lack of relationship may be related to the high production rates of bacteria and the influence of abiotic factors, especially oxic conditions. Approaches such as trophic markers (e.g. stable isotope and/or fatty acid analyses) would be very complementary to the determination of feeding types based on the morphology of the buccal cavity. Such tools would provide a more comprehensive picture of food sources really assimilated by meiofauna and highlight how the use of food sources by meiofauna may change depending on availability. Combining trophic marker data with biomass and production data in food web models would then provide a much more complete overview of the functioning of coastal food webs.

\section{Compliance with ethical standards}




\section{Conflict of interest}

All authors declare that they have no conflict of interest.

\section{Ethical statement}

All applicable international, national and/or institutional guidelines for the sampling, care and use of organisms were followed.

\section{Acknowledgements}

This study forms part of the Ph.D. thesis of L. van der Heijden. This work was financially supported by the University of La Rochelle through a grant provided by the 'Ministère de l'Enseignement Supérieur et de la Recherche'. This work was supported by the CNRS through the CNRS research chair provided to B. Lebreton. Financial support was provided by the Alfred Wegener Institute Helmholtz Centre for Polar and Marine Research, as well as the University of La Rochelle (Mobility for doctoral students) and the German Academic Exchange Service (DAAD: short-term research grant, 2017, no. 57314023). We acknowledge P. Pineau, B. Hussel, S. Horn, M. Burgdorf, M. Paar and N. Lachaussée for their support during fieldwork, and G. Guillou and C. Labrune for their support in the analyses. We thank Q. Bernier for his help in sample processing and analysis. Finally, L. van der Heijden thanks the members of his Ph.D. committee, M. Graeve, N. Niquil and G. Blanchard, for their guidance, as well as two anonymous reviewers whose comments greatly improved the manuscript.

\section{References}

Armonies W, Hellwig-Armonies M (1987) Synoptic patterns of meiofaunal and macrofaunal abundances and specific composition in littoral sediments. Helgoländer Meeresuntersuchungen 41:83-111. doi: 10.1007/BF02365101

Asmus H, Asmus RM (1985) The importance of grazing food chain for energy flow and production in three intertidal sand bottom communities of the northern Wadden Sea. Helgoländer Meeresuntersuchungen 39:273301. doi: 10.1007/BF01992775

Asmus H, Asmus RM (2005) Significance of suspension-feeder systems on different spatial scales. In: Dame RF, Olenin S (eds) The comparative roles of suspension-feeders in ecosystems. Springer Netherlands, pp 199-219

Asmus RM (1983) Benthische und pelagische Primärproduktion und Nährsalzbilanz. Eine Freilanduntersuchung im Watt der Nordsee. Ber. Inst. Meereskunde, Univ. Kiel

Asmus RM, Bauerfeind E (1994) The microphytobenthos of Königshafen—spatial and seasonal distribution on a sandy tidal flat. Helgoländer Meeresuntersuchungen 48:257-276. doi: 10.1007/BF02367040 
Austen MC, Widdicombe S, Villano-Pitacco N (1998) Effects of biological disturbance on diversity and structure of meiobenthic nematode communities. Mar Ecol Prog Ser 174:233-246. doi: 10.3354/meps174233

Azovsky AI, Chertoprood ES, Saburova MA, Polikarpov IG (2004) Spatio-temporal variability of micro- and meiobenthic communities in a White Sea intertidal sandflat. Estuar Coast Shelf Sci 60:663-671. doi: 10.1016/j.ecss.2004.03.005

Baird D, Asmus H, Asmus R (2007) Trophic dynamics of eight intertidal communities of the Sylt-Rømø Bight ecosystem, northern Wadden Sea. Mar Ecol Prog Ser 351:25-41. doi: 10.3354/meps07137

Bergamaschi BA, Tsamakis E, Keil RG, Eglinton TI, Montluçon DB, Hedges JI (1997) The effect of grain size and surface area on organic matter, lignin and carbohydrate concentration, and molecular compositions in Peru Margin sediments. Geochim Cosmochim Acta 61:1247-1260. doi: 10.1016/S0016-7037(96)00394-8

Blanchard GF (1991) Measurement of meiofauna grazing rates on microphytobenthos: is primary production a limiting factor? J Exp Mar Bio Ecol 147:37-46. doi: 10.1016/0022-0981(91)90035-U

Boschker HTS, Wielemaker A, Schaub BEM, Holmer M (2000) Limited coupling of macrophyte production and bacterial carbon cycling in the sediments of Zostera spp. meadows. Mar Ecol Prog Ser 203:181-189. doi: $10.3354 /$ meps 203181

Cammen LM (1991) Annual bacterial production in relation to benthic microalgal production and sediment oxygen uptake in an intertidal sandflat and an intertidal mudflat. Mar Ecol Prog Ser 71:13-25. doi: 10.3354/meps071013

Castel J, Labourg P-J, Escavarage V, Auby I, Garcia ME (1989) Influence of seagrass beds and oyster parks on the abundance and biomass patterns of meio- and macrobenthos in tidal flats. Estuar Coast Shelf Sci 28:71-85.

Cebrián J (1999) Patterns in the fate of production in plant communities. Am Nat 154:449-468. doi: $10.1086 / 303244$

Chardy P, Dauvin JC (1992) Carbon flows in a subtidal fine sand community from the western English Channel: a simulation analysis. Mar Ecol Prog Ser 81:147-161. doi: 10.3354/meps081147

Cnudde C, Werbrouck E, Lepoint G, Vangansbeke D, Moens T, Troch M De (2015) Trophodynamics of intertidal harpacticoid copepods based on stable isotopes and fatty acid profiling. Mar Ecol Prog Ser 524:225-239. doi: $10.3354 /$ meps 11161

Core Team R (2016) R: A language and environment for statistical computing.

Coull BC (1999) Role of meiofauna in estuarine soft-bottom habitats. Aust J Ecol 24:327-343. doi: 10.1046/j.14429993.1999.00979.x

Dale NG (1974) Bacteria in intertidal sediment: Factors related to their distribution. Limnol Oceanogr 19:509-519. 
Danovaro R (1996) Detritus-Bacteria-Meiofauna interactions in a seagrass bed (Posidonia oceanica) of the NW Mediterranean. Mar Biol 127:1-13. doi: 10.1007/BF00993638

Danovaro R, Gambi C (2002) Biodiversity and trophic structure of nematode assemblages in seagrass systems: evidence for a coupling with changes in food availability. Mar Biol 141:667-677. doi: 10.1007/s00227-002$0857-y$

Danovaro R, Gambi C, Mirto S (2002) Meiofaunal production and energy transfer efficiency in a seagrass Posidonia oceanica bed in the western Mediterranean. Mar Ecol Prog Ser 234:95-104. doi: 10.3354/meps234095

Day JWJ, Hall CAS, Kemp MW, Yáñez-Arancibia A (eds) (1989) Estuarine ecology. John Wiley \& Sons, New York

de Jong DJ, de Jonge VN (1995) Dynamics and distribution of microphytobenthic chlorophyll-a in the Western Scheldt estuary (SW Netherlands). Hydrobiologia 311:21-30. doi: 10.1007/BF00008568

de Jonge VN (1980) Fluctuations in the organic carbon to chlorophyll-a ratios for estuarine benthic diatom populations. Mar Ecol Prog Ser 2:345-353. doi: 10.3354/meps002345

de Jonge VN, Bouwman LA (1977) A simple density separation technique for quantitative isolation of microphytobenthos using the coloidal silica LudoxTM. Mar Biol 42:143-148. doi: 10.1007/BF00391564

De Troch M, Gurdebeke S, Fiers F, Vincx M (2001) Zonation and structuring factors of meiofauna communities in a tropical seagrass bed (Gazi Bay, Kenya). J Sea Res 45:45-61. doi: 10.1016/S1385-1101(00)00055-1

De Troch M, Houthoofd L, Chepurnov V, Vanreusel A (2006) Does sediment grain size affect diatom grazing by harpacticoid copepods? Mar Environ Res 61:265-277. doi: 10.1016/j.marenvres.2005.10.004

Dechambenoy CL, Pointier F, Sirou F, Vouvé J (1977) Apport de la thermographie infrarouge aéroportée à la connaissance de la dynamique superficielle des estuaires (système Charente-Seudre-Anse de l' Aiguillon). Acad des Sci 284:1269-1272.

Duarte CM, Cebrián J (1996) The fate of marine autotrophic production. Limnol Oceanogr 41:1758-1766. doi: 10.4319/1o.1996.41.8.1758

Dupuy C, Nguyen Thanh H, Mizrahi D, Jourde J, Bréret M, Agogué H, Beaugeard L, Bocher P (2015) Structure and functional characteristics of the meiofauna community in highly unstable intertidal mudbanks in Suriname and French Guiana ( North Atlantic coast of South America ). Cont Shelf Res 110:39-47. doi: 10.1016/j.csr.2015.09.019

Ellison RL (1984) Foraminifera and meiofauna on an intertidal mudflat, Cornwall, England: Populations; respiration and secondary production; and energy budget. Hydrobiologia 109:131-148. doi: 10.1007/BF00011572

Escaravage V, Garcia ME, Castel J (1989) The distribution of meiofauna and its contribution to detritic pathways in 
Fonseca G, Hutchings P, Gallucci F (2011) Meiobenthic communities of seagrass beds (Zostera capricorni) and unvegetated sediments along the coast of New South Wales, Australia. Estuar Coast Shelf Sci 91:69-77. doi: 10.1016/j.ecss.2010.10.003

Franco MA, Soetaert K, Van Oevelen D, Van Gansbeke D, Costa MJ, Vincx M, Vanaverbeke J (2008) Density, vertical distribution and trophic responses of metazoan meiobenthos to phytoplankton deposition in contrasting sediment types. Mar Ecol Prog Ser 358:51-62. doi: 10.3354/meps07361

765

Frontalini F, Semprucci F, du Châtelet EA, Francescangeli F, Margaritelli G, Rettori R, Spagnoli F, Balsamo M, Coccioni R (2014) Biodiversity trends of the meiofaunal and foraminiferal assemblages of Lake Varano (southern Italy). Proc Biol Soc Washingt 127:7-22. doi: 10.2988/0006-324X-127.1.7

Gallucci F, Steyaert M, Moens T (2005) Can field distributions of marine predacious nematodes be explained by sediment constraints on their foraging success? Mar Ecol Prog Ser 304:167-178. doi: 10.3354/meps304167

Giere O (2009) Meiobenthology: the microscopic motile fauna of aquatic sediments, Second. Springer-Verlag, Berlin Heidelberg

Gouleau D, Jouanneau JM, Weber O, Sauriau PGG (2000) Short- and long-term sedimentation on MontportailBrouage intertidal mudflat, Marennes-Oléron Bay (France). Cont Shelf Res 20:1513-1530. doi: $10.1016 / \mathrm{S} 0278-4343(00) 00035-2$

Guarini J-M, Blanchard GF, Bacher C, Gros P, Riera P, Richard P, Gouleau D, Prou J, Galois R, Sauriau P-G (1998) Dynamics of spatial patterns of microphytobenthic biomass: inferences from a geostatistical analysis of two comprehensive surveys in Marennes-Oléron Bay (France). Mar Ecol Prog Ser 166:131-141.

Guillaumont B (1991) Utilisation de l'imagerie satellitaire pour des comparaisons spatiales et temporelles en zone intertidale. In: Elliott M, Ducrotoy J-P (eds) Estuaries and coasts: spatial and temporal intercomparisons. ECSA19 symposium. Olsen \& Olsen, Fredensborg, pp 63-68

Haubois AG, Guarini JM, Richard P, Fichet D, Radenac G, Blanchard GF (2005) Ingestion rate of the deposit-feeder Hydrobia ulvae (Gastropoda) on epipelic diatoms: Effect of cell size and algal biomass. J Exp Mar Bio Ecol 317:1-12. doi: $10.1016 /$ j.jembe.2004.11.009

Heip C, Vincx M, Vranken G (1985) The ecology of marine nematodes. Ocean Mar Biol Ann Rev 23:399-489.

Hemminga M, Duarte CM (2000) Seagrass ecology, First. Cambridge University Press, Cambridge, Massachusetts

Hicks GRF, Coull BC (1983) The ecology of marine meiobenthic harpacticoid copepods. Ocean Mar Biol Ann Rev 21:67-175. doi: 10.1234/2013/999990.

Higgins RP, Thiel H (1988) Introduction to the study of meiofauna. Smithsonian Institution Press, Washington DC 
Hill MO (1973) Diversity and evenness: a unifying notation and its consequences. Ecology 54:427-432. doi: $10.2307 / 1934352$

Jensen P (1983) Meiofaunal abundance and vertical zonation in a sublittoral soft bottom, with a test of the Haps corer. Mar Biol 74:319-326. doi: 10.1007/BF00403458

Josefson AB, Widbom B (1988) Differential response of benthic macrofauna and meiofauna to hypoxia in the Gullmar Fjord basin. Mar Biol 100:31-40. doi: 10.1007/BF00392952

Kervella S (2009) Dynamique des sédiments fins et mixtes des zones intertidales de la baie de Marennes-Oléron.

Kotwicki L, De Troch M, Urban-Malinga B, Gheskiere T, Weslawski JM (2005a) Horizontal and vertical distribution of meiofauna on sandy beaches of the North Sea (The Netherlands, Belgium, France). Helgol Mar Res 59:255-264. doi: 10.1007/s10152-005-0001-8

Kotwicki L, Szymelfenig M, De Troch M, Urban-Malinga B, Wȩsławski JM (2005b) Latitudinal biodiversity patterns of meiofauna from sandy littoral beaches. Biodivers Conserv 14:461-474. doi: 10.1007/10531-0046272-6

Lavergne C, Beaugeard L, Dupuy C, Courties C, Agogué H (2014) An efficient and rapid method for the enumeration of heterotrophic prokaryotes in coastal sediments by flow cytometry. J Microbiol Methods 105:31-38. doi: 10.1016/j.mimet.2014.07.002

Lebreton B (2009) Analyse de la structure et du fonctionnement du reseau trophique d'un herbier par approche multi-traceurs: tracage isotopique naturel et profils acides gras.

Lebreton B, Richard P, Radenac G, Bordes M, Bréret M, Arnaud C, Mornet F, Blanchard GF (2009) Are epiphytes a significant component of intertidal Zostera noltii beds? Aquat Bot 91:82-90. doi: 10.1016/j.aquabot.2009.03.003

Lebreton B, Richard P, Galois R, Radenac G, Brahmia A, Colli G, Grouazel M, André C, Guillou G, Blanchard GF (2012) Food sources used by sediment meiofauna in an intertidal Zostera noltii seagrass bed: A seasonal stable isotope study. Mar Biol 159:1537-1550. doi: 10.1007/s00227-012-1940-7

Leduc D, Probert PK (2011) Small-scale effect of intertidal seagrass (Zostera muelleri) on meiofaunal abundance, biomass, and nematode community structure. J Mar Biol Assoc United Kingdom 91:579-591. doi: $10.1017 / \mathrm{S} 0025315410001645$

Leduc D, Probert PK, Duncan A (2009) A multi-method approach for identifying meiofaunal trophic connections. Mar Ecol Prog Ser 383:95-111. doi: 10.3354/meps07991

Lee S, Fuhrman JEDA (1987) Relationships between biovolume and biomass of naturally derived marine bacterioplankton. Deep Res Part B Oceanogr Lit Rev 53:1298-1303. doi: 10.1016/0198-0254(87)96080-8 
Leguerrier D, Niquil N, Boileau N, Rzeznik J, Sauriau PG, Le Moine O, Bacher C (2003) Numerical analysis of the food web of an intertidal mudflat ecosystem on the Atlantic coast of France. Mar Ecol Prog Ser 246:17-37. doi: $10.3354 / \operatorname{meps} 246017$

Lorenzen CJ (1966) A method for the continuous measurement of in vivo chlorophyll concentration. Deep Res Oceanogr Abstr 13:223-227. doi: 10.1016/0011-7471(66)91102-8

Lü S, Wang X, Han B (2009) A field study on the conversion ratio of phytoplankton biomass carbon to chlorophylla in Jiaozhou Bay, China. Chinese J Oceanol Limnol 27:793-805. doi: 10.1007/s00343-009-9221-0

Machás R, Santos R (1999) Sources of organic matter in Ria Formosa revealed by stable isotope analysis. Acta Oecologica 20:463-469. doi: 10.1016/S1146-609X(99)00122-8

MacIntyre HL, Geider RJ, Miller DC (1996) Microphytobenthos: The ecological role of the "Secret garden" of unvegetated, shallow-water marine habitats. I. Distribution, abundance and primary production. Estuaries 19:202. doi: $10.2307 / 1352225$

Marbà N, Holmer M, Gacia E, Barron, Marb N (2006) Seagrass beds and coastal biogeochemistry. In: Larkum AWD, Orth RJ, Duarte CM (eds) Seagrasses: biology, ecology and conservation. Dordrecht: Springer, pp $159-192$

Maria TF, Vanaverbeke J, Esteves AM, De Troch M, Vanreusel A (2012) The importance of biological interactions for the vertical distribution of nematodes in a temperate ultra-dissipative sandy beach. Estuar Coast Shelf Sci 97:114-126. doi: 10.1016/j.ecss.2011.11.030

Materatski P, Vafeiadou AM, Ribeiro R, Moens T, Adão H (2015) A comparative analysis of benthic nematode assemblages from Zostera noltii beds before and after a major vegetation collapse. Estuar Coast Shelf Sci 167:256-268. doi: 10.1016/j.ecss.2015.07.001

Materatski P, Ribeiro R, Moreira-Santos M, Sousa JP, Adão H (2018) Nematode biomass and morphometric attributes as descriptors during a major Zostera noltii collapse. Mar Biol 165:1-17. doi: http://dx.doi.org/10.1007/s00227-018-3283-5

Mayer LM (1994) Relationships between mineral surfaces and organic carbon concentrations in soil and sediments. Chem Geol 114:347-363. doi: 10.1016/0009-2541(94)90063-9

McLusky DS, Elliott M (2004) The estuarine ecosystem: ecology, threats and management. OUP, Oxford Moens T, Vincx M (1997) Observations on the feeding ecology of estuarine nematodes. J Mar Biol Assoc United Kingdom 77:211-227.

Moens T, Gansbeke D, Vincx M (1999a) Linking estuarine nematodes to their suspected food. A case study from the Westerschelde Estuary (south-west Netherlands). J Mar Biol Assoc United Kingdom 79:1017-1027. doi: Doi $10.1017 / \mathrm{S} 0025315499001253$ 
Moens T, Verbeeck L, de Maeyer A, Swings J, Vincx M (1999b) Selective attraction of marine bacterivorous nematodes to their bacterial food. Mar Ecol Prog Ser 176:165-178. doi: 10.3354/meps176165

Moens T, Dos Santos GAP, Thompson F, Swings J, Fonsêca-Genevois V, Vincx M, De Mesel I (2005a) Do nematode mucus secretions affect bacterial growth? Aquat Microb Ecol 40:77-83. doi: 10.3354/ame040077

Moens T, Bouillon S, Gallucci F (2005b) Dual stable isotope abundances unravel trophic position of estuarine nematodes. J Mar Biol Assoc United Kingdom 85:1401-1407. doi: 10.1017/S0025315405012580

Moens T, Braeckman U, Derycke S, Fonseca G, Gallucci F, Gingold R, Guilini K, Ingels J, Leduc D, Vanaverbeke J, Van Colen C, Vanreusel A, Vincx M (2013) Ecology of free-living marine nematodes. In: Schmidt-Rhaesa A (ed) Nematoda. De Gruyter, pp 109-152

Ndaro SGM, Olafsson E (1999) Soft-bottom fauna with emphasis on nematode assemblage structure in a tropical intertidal lagoon in Zanzibar, eastern Africa: I. spatial variability. Hydrobiologia 405:133-148. doi: 10.1023/A

Oksanen J, Blanchet FG, Friendly M, Kindt R, Legendre P, Mcglinn D, Minchin PR, O'hara RB, Simpson GL, Solymos P, Henry M, Stevens H, Szoecs E, Wagner H, Oksanen MJ (2017) vegan: community ecology package.

Pacella SR, Lebreton B, Richard P, Phillips D, DeWitt TH, Niquil N (2013) Incorporation of diet information derived from Bayesian stable isotope mixing models into mass-balanced marine ecosystem models: A case study from the Marennes-Oléron Estuary, France. Ecol Modell 267:127-137. doi: 10.1016/j.ecolmodel.2013.07.018

Pascal P-Y (2008) Devenir des bacteries dans les reseaux trophiques des vasieres intertidales: le cas de Brouage (Baie de Marennes-Oleron). Sciences du Vivant [q-bio]. Universite de La Rochelle, 2008. Francais.

Pascal P-Y, Dupuy C, Richard P, Mallet C, du Châtelet EA, Niquil N (2009) Seasonal variation in consumption of benthic bacteria by meio- and macrofauna in an intertidal mudflat. Limnol Oceanogr 54:1048-1059. doi: 10.4319/lo.2009.54.4.1048

Pedersen O, Borum J, Duarte CM, Fortes MD (1998) Oxygen dynamics in the rhizosphere of Cymodocea rotundata. Mar Ecol Prog Ser 169:283-288. doi: 10.3354/meps169283

Pinckney JL, Zingmark RG (1993) Modeling the annual production of intertidal benthic microalgae in estuarine ecosystems. J Phycol 29:396-407. doi: 10.1111/j.1529-8817.1993.tb00140.x

Platt HM, Warwick RM (1983) Free-living marine nematodes. Part 1: British enoplids. Synopsis of the British Fauna (new) No. 28. Cambridge University Press, for the Linnean Society of London and the Estuarine and Brackish-water Sciences Association

Platt HM, Warwick RM (1988) Free-living marine nematodes. Part II: British chromadorids. Synopsis of the British Fauna (new) No. 38. 
Ravail B, Héral M, Maestrini S, Robert J-M (1988) Incidence du débit de la Charente sur la capacité biotique du bassin ostréicole du bassin de Marennes-Oléron. J Rech Ocean 13:48-52.

Reise K (1985) Tidal flat ecology: An experimental approach to species interactions, Ecological. Berlin SpringerVerlag

Reise K, Kohlus J (2008) Seagrass recovery in the Northern Wadden Sea? Helgol Mar Res 62:77-84. doi: 10.1007/s10152-007-0088-1

Rzeznik-Orignac J, Fichet D (2012) Experimental estimation of assimilation rates of meiofauna feeding on 14Clabelled benthic diatoms. J Exp Mar Bio Ecol 432-433:179-185. doi: 10.1016/j.jembe.2012.06.019

Rzeznik-Orignac J, Fichet D, Boucher G (2003) Spatio-temporal structure of the nematode assemblages of the Brouage mudflat (Marennes Oléron, France). Estuar Coast Shelf Sci 58:77-88. doi: 10.1016/S02727714(03)00061-1

Rzeznik-Orignac J, Boucher G, Fichet D, Richard P (2008) Stable isotope analysis of food source and trophic position of intertidal nematodes and copepods. Mar Ecol Prog Ser 359:145-150. doi: 10.3354/meps07328

Saint-Béat B, Dupuy C, Bocher P, Chalumeau J, De Crignis M, Fontaine C, Guizien K, Lavaud J, Lefebvre S, Montanié H, Mouget J-L, Orvain F, Pascal P-Y, Quaintenne G, Radenac G, Richard P, Robin F, Vézina AF, Niquil N (2013) Key features of intertidal food webs that support migratory shorebirds. PLoS One 8:1-17. doi: 10.1371/journal.pone.0076739

Seinhorst JW (1959) A rapid method for the transfer of nematodes from fixative to anhydrous glycerin. Nematologica 4:67-69. doi: 10.1163/187529259X00381

Semprucci F, Balsamo M (2012) Free-living marine nematodes as bioindicators: past, present and future perspectives. Environ Res J 6:17-36.

Semprucci F, Boi P, Manti A, Harriague AC, Rocchi M, Colantoni P, Papa S, Balsamo M (2010) Benthic communities along a littoral of the Central Adriatic Sea (Italy). Helgol Mar Res 64:101-115. doi: 10.1007/s10152-009-0171-x

Sikora WB, Sikora JP (1982) Ecological implications of the vertical distribution of meiofauna in salt marsh sediments. Estuar Comp 269-282. doi: 10.1016/B978-0-12-404070-0.50022-3

Smidt ELB (1951) Animal production in the Danish Waddensea. Meddr Kommn Danm Fisk-og Havunders, Ser Fisk $11: 1-151$.

Smol N, Willems KA, Govaere JCR, Sandee AJJ (1994) Composition, distribution and biomass of meiobenthos in the Oosterschelde estuary (SW Netherlands). Hydrobiologia 282-283:197-217. doi: 10.1007/BF00024631

Soetaert K, Vincx M, Wittoeck J, Tulkens M (1995) Meiobenthic distribution and nematode community structure in 
Steyaert M, Herman PMJ, Moens T, Widdows J, Vincx M (2001) Tidal migration of nematodes on an estuarine tidal flat (the Molenplaat, Schelde Estuary, SW Netherlands). Mar Ecol Prog Ser 224:299-304. doi: 10.3354/meps 224299

Steyaert M, Vanaverbeke J, Vanreusel A, Barranguet C (2003) The importance of fine-scale, vertical profiles in characterising nematode community structure. Estuar Coast Shelf Sci 58:353-366. doi: 10.1016/S02727714(03)00086-6

Steyaert M, Moodley L, Nadong T, Moens T, Soetaert K, Vincx M (2007) Responses of intertidal nematodes to short-term anoxic events. J Exp Mar Bio Ecol 345:175-184. doi: 10.1016/J.JEMBE.2007.03.001

Suzuki R, Shimodaira H (2015) Hierarchical clustering with p-values via multiscale bootstrap resampling.

Thornton DCO, Dong LF, Underwood GJC, Nedwell DB (2002) Factors affecting microphytobenthic biomass, species composition and production in the Colne Estuary (UK). Aquat Microb Ecol 27:285-300. doi: $10.3354 / \mathrm{ame} 027285$

Tietjen J, Lee J (1977) Feeding behaviour of marine nematodes. In: Coul B (ed) Ecology of Marine Benthos. University of South Carolina Press, Columbia, USA, pp 21-35

Underwood GJC, Kromkamp J (1999) Primary production by phytoplankton and microphytobenthos in estuaries. Adv Ecol Res 29:93-139.

Underwood GJC, Paterson DM (1993) Recovery of intertidal benthic diatoms after biocide treatment and associated sediment dynamics. J Mar Biol Assoc United Kingdom 73:25-45. doi: 10.1017/S002531540003263X

Vafeiadou AM, Materatski P, Adão H, De Troch M, Moens T (2014) Resource utilization and trophic position of nematodes and harpacticoid copepods in and adjacent to Zostera noltii beds. Biogeosciences 11:4001-4014. doi: $10.5194 /$ bg-11-4001-2014

Vanaverbeke J, Soetaert K, Vincx M (2004) Changes in morphometric characteristics of nematode communities during a spring phytoplankton bloom deposition. Mar Ecol Prog Ser 273:139-146. doi: 10.3354/meps273139

Vizzini S, Sarà G, Michener RH, Mazzola A (2002) The role and contribution of the seagrass Posidonia oceanica (L.) Delile organic matter for secondary consumers as revealed by carbon and nitrogen stable isotope analysis. Acta Oecologica 23:277-285. doi: 10.1016/S1146-609X(02)01156-6

Warwick RM (1971) Nematode associations in the Exe Estuary. J Mar Biol Assoc United Kingdom 51:439-454. doi: $10.1017 / \mathrm{S} 0025315400031908$

Warwick RM, Clarke KR (1998) Taxonomic distinctness and environmental assessment. J Appl Ecol 35:532-543. Warwick RM, Price R (1979) Ecological and metabolic studies on free-living nematodes from an estuarine mud-flat. 
947 Wentworth CK (1922) A scale of grade and class terms for clastic sediments. J Geol 30:377-392. doi: $10.1086 / 622910$

Wetzel MA, Fleeger JW, Powers SP (2001) Effects of hypoxia and anoxia on meiofauna: A review with new data from the Gulf of Mexico. In: Nancy N. Rabalais RET (ed) Coastal Hypoxia: Consequences for Living Resources and Ecosystems. American Geophysical Union, pp 165-184

952 Wieser W (1953) Die Beziehungen zwischen Mundhohlengestalt, Ernahrungsweise und Vorkommen bei freilebenden marinen Nematoden. Ark Zool (Ser 2) 4:439-484.

954 Wieser W, Kanwisher J (1960) Growth and metabolism in a marine nematode, Enoplus communis Bastian. Z Vgl Physiol 43:29-36. doi: 10.1007/BF00351200

956 